Canadian

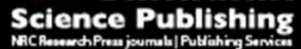

Canadian Journal of Forest Research Revue canadienne de recherche forestière

\title{
Thinning effect on understory community and photosynthetic characteristics in a subtropical Pinus massoniana plantation
}

\begin{tabular}{|c|c|}
\hline Journal: & Canadian Journal of Forest Research \\
\hline Manuscript ID & cjfr-2017-0082.R1 \\
\hline Manuscript Type: & Article \\
\hline Date Submitted by the Author: & 18-Apr-2017 \\
\hline Complete List of Authors: & $\begin{array}{l}\text { Cheng, Chuanpeng; Institute of Geographic Sciences and Natural } \\
\text { Resources Research, ; } \\
\text { Wang, Yidong; Tianjin Normal University, Tianjin Key Laboratory of Water } \\
\text { Resources and Environment } \\
\text { Fu, Xiaoli; Institute of Geographic Sciences and Natural Resources } \\
\text { Research, Chinese Academy of Sciences, } \\
\text { Xu, Mingjie; Institute of Geographic Sciences and Natural Resources } \\
\text { Research Chinese Academy of Sciences } \\
\text { Dai, Xiaoqin; Institute of Geographic Sciences and Natural Resources } \\
\text { Research Chinese Academy of Sciences } \\
\text { Wang, HuiMin; Qianyanzhou Ecological Station, }\end{array}$ \\
\hline Keyword: & $\begin{array}{l}\text { Thinning, Forest management, Understory diversity, Photosynthesis, Pinus } \\
\text { massoniana plantation }\end{array}$ \\
\hline $\begin{array}{r}\text { Is the invited manuscript for } \\
\text { consideration in a Special } \\
\text { Issue? : }\end{array}$ & N/A \\
\hline
\end{tabular}




\section{Thinning effect on understory community and photosynthetic}

2 characteristics in a subtropical Pinus massoniana plantation

3 Chuanpeng Cheng ${ }^{1,2}$, Yidong $\mathrm{Wang}^{3}$, Xiaoli $\mathrm{Fu}^{1}$, Mingjie $\mathrm{Xu}^{1,4}$, Xiaoqin Dai ${ }^{1}$,

$4 \quad$ Huimin Wang ${ }^{1,2,5^{*}}$

$5{ }^{1}$ Qianyanzhou Ecological Research Station, Key Laboratory of Ecosystem Network

6 Observation and Modeling, Institute of Geographic Sciences and Natural Resources

7 Research, Chinese Academy of Sciences, Beijing 100101, China

$8{ }^{2}$ College of Resources and Environment, University of Chinese Academy of

$9 \quad$ Sciences, Beijing 100190, China

$10{ }^{3}$ Tianjin Key Laboratory of Water Resources and Environment, Tianjin Normal

11 University, Tianjin 300387, China

$12{ }^{4}$ College of Agronomy, Shenyang Agricultural University, Shenyang 110866, China,

135 Jiangxi Provincial Key Laboratory of Ecosystem Processes and Information, Ji'an $14 \quad 343725$, China

*Corresponding author: Huimin Wang, Address: Key Laboratory of Ecosystem Network Observation and Modeling, Institute of Geographic Sciences and Natural Resources Research, No. 11A, Datun Road, Chaoyang District, Beijing 100101, China. Tel: +86 10-64888896, Fax: +86 10-64888896.

E-mail address: wanghm@,igsnrr.ac.cn (H. Wang). 
Abstract: Thinning forest stands changes biotic and abiotic conditions, subsequently altering understory communities including their photosynthetic characteristics. We investigated the effects of thinning (25\% basal area decrease) in a subtropical Pinus massoniana plantation at two post-thinning times: $0.5\left(\mathrm{PT}_{0.5-\mathrm{yr}}\right)$ and 2.5 years ( $\left.\mathrm{PT}_{2.5 \text {-yrs }}\right)$. Thinning $\left(\mathrm{PT}_{0.5-\mathrm{yr}}\right.$ and $\left.\mathrm{PT}_{2.5 \text {-yrs }}\right)$ significantly increased understory density $(+104.9 \%$ and $+142.4 \%)$, aboveground biomass $(+191.1 \%$ and $+239.2 \%)$, Shannon-Wiener index and Pielou index, and decreased the Simpson index $(p<0.05)$. Species richness significantly increased at $\mathrm{PT}_{0.5-\mathrm{yr}}$, and decreased at $\mathrm{PT}_{2.5-\mathrm{yrs}}(p<0.05)$. Photosynthetic characteristics of three dominant species (Woodwardia japonica, Dryopteris championii and Dicranopteris dichotoma) new-leaf and old-leaf showed different variation after 0.5 and 2.5 years post-thinning depending on their various adaptive strategies. Generally, thinning improved leaf carbon fixation capacity of these dominant plants (except $W$. japonica old-leaf). Leaf photosynthetic characteristics of these species exhibited some common changes with respect to leaf morphological attributes and chlorophyll content. Thinning increased new-leaf length (or width) and reduced old-leaf chlorophyll b concentration at $\mathrm{PT}_{0.5-\mathrm{yr}}$, while reduced new-leaf length, specific leaf area, and all-leaf chlorophyll concentration at

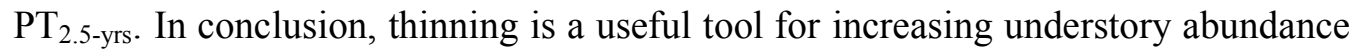
and carbon fixation capacity of some fern species.

Keywords: Thinning, Forest management, Understory diversity, Photosynthesis, Pinus massoniana plantation, Subtropical China

Introduction 
Understory plays an important role in providing wildlife habitat and conserving biodiversity in forests (Ishii et al. 2008; Sullivan et al. 2009). It affects both belowground and aboveground ecological processes, such as nutrient cycling, litter decomposition, and species succession (Nilsson and Wardle 2005; Liu et al. 2012). Although the biomass proportion of understory is small in most forests types (especially in mature plantation) around the world (Wang et al. 2006; Li et al. 2013), its impact on the forest carbon fixation and nutrients cycles should be highlighted (Nilsson et al., 2005). Understory usually distributes most of its productivity to the leaves and fine roots where carbon and nutrient turnover rates are significantly higher than in trees (Chiang and Brown 2010). So, understory community dynamics and carbon exchange capacity (carbon fix and release rate per biomass) is an important consideration for forest management (Hanley et al. 2006; Yan et al. 2013). Thinning, an important forest management practice, has been found to have complex effects on understory biodiversity after different time post-thinning (He and Barclay 2000; Gajardo-Caviedes 2005; Raunikar et al. 2010). Many factors (such as thinning intensities, thinning prescriptions, site-specific conditions and sampling time) have considerable influence on these uncertain results (Taki et al. 2010; Lindgren and Sullivan 2013). Research methods may account for important variations, because most research is based on surveys in the same plot at different times post-thinning (Wolk and Rocca 2009; Lindgren and Sullivan 2013). Species phenological differences and inter-annual variation of climate conditions have often been ignored (Yirdaw and Luukkanen 2004; Xu et al. 2014a). This could lead to 
uncertainty in thinning effects, as these differences are important in forest structure and function (Yan et al. 2013). Therefore, it is necessary to consider the response of understory communities after various post-thinning times under the same climate conditions.

Thinning has the potential to impact leaf traits (such as nitrogen content, leaf mass per area, chlorophyll content, and leaf gas exchange) through alterations of microenvironments (especially light and soil conditions) (Moreno-Gutiérrez et al. 2011). Generally, leaf traits vary under different suites of environmental variables (Forrester et al. 2012). Different species also show various responses to same suites of environmental variables depending on their various adaptive strategies (variation of leaf traits, resource use pattern and efficiency difference and so on) (Chiang and Brown 2010; Gspaltl et al. 2013; Xu et al. 2014b). For example, Dicranopteris dichotoma (Thunb.) Bernh. possessed higher $\mathrm{N}$ and $\mathrm{P}$ utilization rates and higher leaf $\mathrm{N}$ and $\mathrm{P}$ content than Woodwardia japonica (Linn. f.) Sm) across a whole ecological restoration chronosequence in subtropical China (Wu et al. 2013; Chen et al. 2016). In addition, leaf physiological and morphological adaptations to the environments may different between foliar development stages (Catoni et al. 2012). Rodríguez-Calcerrada et al. (2008) investigated light acclimation of oak Quercus petraea from low-light exposure (LL: $5.3 \%$ of ambient irradiance) to high-light exposure (HL: 70\% of ambient irradiance) either before leaf flushing (LL-HLBF plants) or after full leaf expansion (LL-HLAF plants), they found that morphological adaptation of leaves of LL-HLBF plants enhanced photosynthetic capacity per unit 
leaf area, whereas leaves of LL-HLAF plants enhanced both mass- and area-based photosynthetic capacity. Thus, examining the influence of thinning on the different age leaf traits and physiological processes of various species can provide insights into the effects of thinning on understory communities and forest productivity.

Pinus massoniana, a native evergreen conifer, is commonly used as a pioneer species for degraded ecosystem restoration (Wang et al. 2015). Many pure $P$. massoniana plantations were established in subtropical China in the 1980s, and have provided many wood products and increased world carbon sinks (Peng et al. 2008; Piao et al. 2009). Piao et al. (2009) estimated a net carbon sink of 0.096 Pg carbons per year in this region, and this makes China's carbon sink comparable to that in geographic Europe. However, their development has led to many problems, such as declines in soil fertility, frequent pest outbreaks, and soil food web changes (Ji et al. 2011; Chen et al. 2016). Given the low carbon fixation capacity and poor crop quality of pure pine plantations, thinning has potential to increase forest productivity (Peng et al. 2008; Yan et al. 2013), while at the same time providing a useful model for studying the effects of thinning on understory communities and their photosynthetic characteristics.

In this study, we investigated the properties of understory communities (density, biomass, and species diversity) as well as the age-specific photosynthetic characteristics of the leaves (morphological attributes, chlorophyll content, and leaf gas exchange) of three dominant herbaceous species in a subtropical P. massoniana plantation under the same climate conditions 0.5 and 2.5 years after thinning. Our 
109

110

111

112

113

114

115

116

117

118

119

120

121

122

123

124

125

126

127

128

129

130

goal was to assess the effects of thinning over time. We hypothesized that (i) understory community density, aboveground biomass, and species diversity will increase soon after thinning due to improvement in the light environment, and then will decrease with soil nutrient consumption and understory light environment recovery, and (ii) leaves of different ages will exhibit different gas exchange responses to environmental conditions, morphological attributes, and chlorophyll content 0.5 and 2.5 years post-thinning depending on their various adaptive strategies.

\section{Materials and methods}

\section{Experimental site}

This experiment was carried out at the Qianyanzhou Ecological Station of the Chinese Academy of Sciences $\left(26^{\circ} 44^{\prime} 39^{\prime \prime} \mathrm{N}, 115^{\circ} 03^{\prime} 33^{\prime \prime} \mathrm{E}\right.$, and $102 \mathrm{~m}$ in elevation above sea level), which is located in a typical hilly red-soil region of subtropical China. The soil is classified as a Typic Dystrudept in the USDA system (Wen et al. 2010; Wang et al. 2012). The site is controlled by a warm and humid monsoon climate (annual mean air temperature: $18.0{ }^{\circ} \mathrm{C}$; annual mean precipitation: 1509.0 mm). About 1980, coniferous trees, including Masson pine (P. massoniana Lamb.), Slash pine (Pinus elliottii Englem.), and Chinese fir (Cunninghamia lanceolata Hook.), were planted at a density of about 1460.0 stems $^{-1}$ to combat soil degradation. The P. massoniana plantation understory is dominated by Loropetalum chinense (R. Br.) Oliver, Vaccinium bracteatum Thunb., Woodwardia japonica, Dryopteris championii (Benth.) C. Chr., and Dicranopteris dichotoma (Fu et al. 
131

132

133

134

135

136

137

138

139

140

141

142

143

144

145

146

147

148

149

150

151

152

2016). Our field studies did not involve endangered or protected species.

\section{Experimental design}

The experiment was a completely randomized design with three treatments and three replicate plots $(30 \times 30 \mathrm{~m}$, located on moderately steep slopes and 15-20 m apart). The three treatments were: Unthinned; $\mathrm{PT}_{0.5-\mathrm{yr}}$, with thinning treatments in December

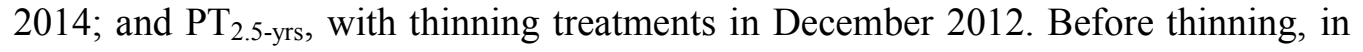
December 2012, P. massoniana trees in the plots had a mean diameter at breast height of $15.9 \mathrm{~cm}$, a mean stand density of $1329.0 \mathrm{stems} \mathrm{ha}^{-1}$ and a basal area of 26.4 $\mathrm{m}^{2} \mathrm{ha}^{-1}$. The shrubs in all the plots were cut down for ease of operation, following standard practice, but the herbs were retained. Approximately $25 \%$ of the basal area was reduced when the thinning treatments were applied, and most of the slash (except for the woody parts of trees) was left on the site. 0.5 and 2.5 years after thinning, the stands had a mean diameter at breast height of 17.3 and $17.6 \mathrm{~cm}$, a mean stand density of 849.0 and 825.0 stems ha ${ }^{-1}$, and a basal area of 19.9 and $20.1 \mathrm{~m}^{2}$ $\mathrm{ha}^{-1}$, respectively. Effects of thinning on understory communities and their photosynthetic characteristics were assessed in July 2015, when 0.5 and 2.5 years had passed after the two thinning treatments $\left(\mathrm{PT}_{0.5-\mathrm{yr}}\right.$ and $\left.\mathrm{PT}_{2.5-\mathrm{yrs}}\right)$. We choose this time because there was a clear summer drought (with intense solar irradiation and little precipitation) in this month, and the understory community was likely to respond acutely (Chiang and Brown 2010; Yan et al. 2015). We also analyzed soil chemical properties, canopy structure and light transmittance, as well as understory community structure and species diversity before thinning in December 2014. There 
153

154

155

156

157

158

159

160

161

162

163

164

165

166

167

168

169

170

171

172

173

174

were no significant differences (soil chemical properties, canopy structure and light transmittance, as well as understory community structure and species diversity) between Unthinned and $\mathrm{PT}_{0.5 \text {-yr }}$ before thinning, except with respect to understory community species diversity (Table A1, A2).

\section{Soil sampling and analyses}

Soil samples were collected in December 2014 and July 2015 (before and after thinning was applied for $\mathrm{PT}_{0.5-\mathrm{yr}}$ ) using a $45-\mathrm{mm}$-diameter hand auger at depths of $0-10 \mathrm{~cm}$ and $10-20 \mathrm{~cm}$ in each plot. One soil core was randomly collected in each of the nine $10 \times 10 \mathrm{~m}$ subplots, and then the nine soil cores combined into one composite soil sample for each depth in each plot (Fig. A1). One part of the sample was air-dried for soil $\mathrm{pH}$ measurement in a 1:2.5 soil:water suspension. The other was extracted in $2 \mathrm{M} \mathrm{KCl}$ solution for inorganic nitrogen (IN) content, including measurement of ammonium nitrogen $\left(\mathrm{NH}_{4}{ }^{+} \mathrm{N}\right)$ and nitrate nitrogen $\left(\mathrm{NO}_{3}{ }^{-} \mathrm{N}\right)$, by continuous flow on an auto analyzer (Bran + Luebbe, Germany).

\section{Measurement of canopy structure and light transmittance}

Canopy structure and light transmittance were measured with TRAC (Tracing Radiation and Architecture of Canopies, Canada) and hemispherical photography above the understory on sunny days before (24 November 2014) and after (25 July 2015) thinning was applied at $\mathrm{PT}_{0.5-\mathrm{yr}}$. The TRAC measurements and hemispherical photographs were taken in the morning and evening, respectively.

The leaf area index (LAI) and effective plant area index (PAIe) in each plot were calculated from the TRAC measurements by TRACWIN. Canopy openness, 
175 total solar radiation transmittance $\left(\mathrm{T}_{\text {tot }}\right)$, direct solar radiation transmittance $\left(\mathrm{T}_{\mathrm{dir}}\right)$,

176 and diffuse solar radiation transmittance $\left(\mathrm{T}_{\mathrm{dif}}\right)$ of the canopy were analyzed from the

177 digital hemispherical photographs by Sidelook and GLA (Gap Light Analyzer).

\section{Analysis of understory community}

179 Understory was surveyed in December 2014 and July 2015 (before and after

180 thinning was applied for $\left.\mathrm{PT}_{0.5 \text {-yr }}\right)$. Five permanent square subplots $(5 \times 5 \mathrm{~m})$ in each

181 plot were demarcated to survey the shrub layer. In each subplot, one $1 \times 1 \mathrm{~m}$

182 permanent quadrat was delimited for the herb survey (Fig. A1). Species composition

183 and number were surveyed for the shrub and herb layers, and representative plants of

184 the surveyed species were collected outside the permanent survey plots for long-term

185 study. The plants were oven-dried at $65{ }^{\circ} \mathrm{C}$ for $48 \mathrm{~h}$ and weighed to calculate 186 aboveground biomass.

187 Density and aboveground biomass were calculated as the average density and 188 aboveground biomass. Density sum and aboveground biomass sum were the sum of 189 the total density and aboveground biomass per species in all the treatments at the two 190 sampling dates. Total density and total aboveground biomass were calculated as the 191 total density and aboveground biomass of all the species in each treatment at each 192 sampling date. Species richness $(S)$ was calculated as the mean number of species 193 (Magurran 1988). The Shannon-Wiener index $\left(H^{\prime}\right)$, Simpson index $(D)$, and Pielou 194 index $(J)$ were calculated according to equation 1-3:

$195 \quad H^{\prime}=\frac{N \ln N-\sum n \ln n}{N}$

$196 \quad D=\sum(n / N)(n / N)$ 
$197 J=\frac{H^{\prime}}{\ln S}$

198 where $N$ is the total number of understory species and $n$ is the number of individuals

199 of each species per plot. Variation in the density, aboveground biomass, and species

200 diversity between December 2014 and July 2015 were also estimated by calculating

201 the difference between the two sampling dates.

202

203

204

205

206

207

208

209

\section{Analysis of leaf morphological attributes and chlorophyll content}

Leaf morphological attributes and chlorophyll content of the three dominant plant species (W. japonica, D. championii, and D. dichotoma) (Table A2) in each plot were measured in July 2015 after thinning. For each species, three new and three old representative leaves (same location on stem and similar size and growth state for every leaf type) of three representative plants (plants with average size and growth state on the basis of understory surveys) were collected (except D. championii new leaves due to their smaller number).

Leaf morphological attributes were measured by scanning six leaves of each type in every plot on an A3 flatbed scanner (HP M1522n) to obtain leaf length (L), width (W), and surface area (SA). The images were analyzed by Sidelook and Image J. The leaves were then oven-dried at $65{ }^{\circ} \mathrm{C}$ for $48 \mathrm{~h}$ and weighed to calculate biomass. Specific leaf area (SLA) was the ratio of leaf surface area to biomass.

The three leaves of each type for chlorophyll content measurement in every plot were cut into pieces and extracted $(0.100 \mathrm{~g})$ in $10 \mathrm{ml}$ dimethyl sulfoxide for $72 \mathrm{~h}$ in darkness. OD645 and OD663 of the extracts were analyzed using a UV-Visible spectrophotometer (UV-1601, Shimadzu Corporation, Japan). Chlorophyll a $\left(\mathrm{Chl}_{\mathrm{a}}\right), \mathrm{b}$ 
$219\left(\mathrm{Chl}_{\mathrm{b}}\right)$, and total $\left(\mathrm{Chl}_{\text {tot }}\right)$ concentrations were calculated using equation 4-6 (Arnon 220 1949):

$\mathrm{Chl}_{\mathrm{b}}=0.3 \times(22.90 \times 0 \mathrm{D} 645-4.68 \times 0 \mathrm{0D} 663)$

$\mathrm{Chl}_{\text {tot }}=0.3 \times(20.21 \times 0 \mathrm{0D} 645+8.02 \times 0 \mathrm{D} 663)$

224

225

226

227

\section{Analysis of leaf gas exchange}

Leaf gas exchange of the three dominant herbaceous plants in each plot was measured in July 2015 after thinning. The net photosynthetic rate and the light response curve of new and old representative leaves were measured between 09:00 and 12:00 hours on sunny days with a portable photosynthesis system (LI-6400XT, Li-Cor, Inc., USA) equipped with a LED Source Leaf Chamber and a $\mathrm{CO}_{2}$ injector. The airflow was 500 umol s${ }^{-1}$, leaf temperature was $29.5-30.5^{\circ} \mathrm{C}$, and humidity was 50-60\%. Leaves were acclimated to a saturating photosynthetic photon flux density (PPFD) of $1000 \mathrm{umol} \mathrm{m}^{-1} \mathrm{~s}^{-1}$ and a $\mathrm{CO}_{2}$ concentration $\left[\mathrm{CO}_{2}\right]$ of $400 \mathrm{umol} \mathrm{mol}{ }^{-1}$ until photosynthetic rates stabilized. Under these conditions, the net photosynthetic rate $(A)$ was defined as the mean of three consecutive measurements. Photon irradiances were then decreased in sequence to $1500,1200,1000,900,800,700,600,500,400$, $300,200,100,80,50,20$, and $0 \mathrm{umol} \mathrm{m}^{-1} \mathrm{~s}^{-1}$. Leaf sections enclosed in the chamber were digitized with an A3 flatbed scanner to obtain leaf surface area.

$$
\text { Dark respiration rate }(R d) \text {, light saturation point }(L S P) \text {, light compensation point }
$$
$(L C P)$, apparent quantum efficiency $(A Q E)$, and maximum net photosynthetic rate (Amax) were calculated by fitting the light response curves to a Mitscherlich 
241

242

243

244

245

246

247

248

249

250

251

252

253

254

255

256

257

258

259

260

261

262

nonlinear function using Photosynthesis Work Bench Software (Potvin et al. 1990).

\section{Statistical analyses}

Independent sample $t$-tests were used to examine the differences (soil chemical properties, canopy structure and light transmittance, and understory community structure) before thinning, and the differences (leaf gas exchange, morphological attributes, and chlorophyll content) of the two leaf types. Multiple comparisons were performed using a one-way ANOVA with a Duncan's HSD post hoc test. Stepwise multiple linear analyses examined the relationships between the understory community parameters and the environmental conditions, the relationships between the leaf gas exchange and the environmental conditions, the relationships between the leaf gas exchange with the leaf morphological attributes and chlorophyll content for all the treatments. The assumptions of the ANOVA and linear regression for the data set were verified prior to analysis. The data were $\ln (\mathrm{x})$-transformed during the regression analysis. Significant differences were assessed at the $p<0.05$ level. These analyses were processed with SPSS Version 10.0 (SPSS Inc., USA).

\section{Results}

\section{Soil chemical properties}

Thinning significantly decreased soil nitrate nitrogen $\left(\mathrm{NO}_{3}{ }^{-} \mathrm{N}\right)$ and inorganic nitrogen (IN) in the 0-10 cm layer at $\mathrm{PT}_{0.5-\mathrm{yr}}$ and $\mathrm{PT}_{2.5 \text {-yrs }}$ in July 2015, and these two properties at $\mathrm{PT}_{0.5-\mathrm{yr}}$ were significantly lower than at $\mathrm{PT}_{2.5-\mathrm{yrs}}($ Table 1$)$. This may indicate that the values of the soil chemical properties had decreased significantly after 0.5 year, and then partially recovered, coming close to the original level after 
263

264

265

266

267

268

269

270

271

272

273

274

275

276

277

278

279

280

281

282

283

284

2.5 years post-thinning.

\section{Canopy structure and light transmittance}

Thinning significantly decreased leaf area index (LAI) and effective plant area index (PAIe), and increased canopy openness, total solar radiation transmittance $\left(\mathrm{T}_{\mathrm{tot}}\right)$, direct solar radiation transmittance $\left(\mathrm{T}_{\text {dir }}\right)$, and diffuse solar radiation transmittance ( $\mathrm{T}_{\text {dif }}$ ) at $\mathrm{PT}_{0.5-\mathrm{yr}}$ in July 2015 (Table 1 ). These variables were not significantly different at $\mathrm{PT}_{2.5 \text {-yrs }}$ from those in the Unthinned. $\mathrm{T}_{\text {tot }}, \mathrm{T}_{\text {dir }}$, and $\mathrm{T}_{\text {dif }}$ at $\mathrm{PT}_{0.5-\mathrm{yr}}$ were also significantly higher than at $\mathrm{PT}_{2.5-\mathrm{y} \text { rs. }}$. These results indicate that light availability in the understory increased significantly after 0.5 year, and then partially decreased again, close to the original level after 2.5 years post-thinning.

\section{Understory structure and species diversity}

W. japonica, D. championii, and D. dichotoma were the dominant species in the understory community. Together they accounted for $53.0 \%$ and $67.0 \%$ of the total density and aboveground biomass in all the treatments at the two sampling dates, respectively (Table A2).

Thinning significantly led to an increase of understory density and aboveground biomass $\left(\mathrm{PT}_{0.5-\mathrm{y} r}:+104.9 \%\right.$ and $+191.1 \%$; $\mathrm{PT}_{2.5-\mathrm{yrs}}:+142.4 \%$ and $\left.+239.2 \%\right)$ in July 2015, and their values at $\mathrm{PT}_{0.5 \text {-yr }}$ were still significantly lower than at $\mathrm{PT}_{2.5 \text {-yrs. }}$ The density increases of the two treatments $\left(\mathrm{PT}_{0.5-\text {-yr }}: 81.7\right.$ plants $\mathrm{m}^{-2} ; \mathrm{PT}_{2.5 \text {-yrs }}: 79.4$ plants $\mathrm{m}^{-2}$ ) were not significantly different, while the aboveground biomass increase at $\mathrm{PT}_{0.5-\mathrm{yr}}\left(467.0 \mathrm{~g} \mathrm{~m}^{-2}\right)$ was greater than at $\mathrm{PT}_{2.5-\mathrm{yrs}}\left(388.1 \mathrm{~g} \mathrm{~m}^{-2}\right)$.

Comparing the values of the species diversity indexes in July 2015 and their 
variation between December 2014 and July 2015, thinning significantly increased the understory communities' Shannon-Wiener index $\left(H^{\prime}\right)$ and Pielou index $(J)$, and decreased their Simpson index $(D)$ at $\mathrm{PT}_{0.5-\mathrm{yr}}$ and $\mathrm{PT}_{2.5 \text {-yrs. Thinning significantly }}$ increased the communities' Species richness $(S)$ at $\mathrm{PT}_{0.5-\mathrm{yr}}$ but significantly decreasing again at $\mathrm{PT}_{2.5 \text {-yrs }}$ (Table A1, Fig. 1).

\section{Leaf morphological attributes and chlorophyll content of the three dominant}

\section{herbaceous plants}

For W. japonica, thinning significantly increased new-leaf length (L) (8.3\%), and decreased new-leaf chlorophyll b concentrations $\left(\mathrm{Chl}_{\mathrm{b}}\right)(25.0 \%)$ and old-leaf $\mathrm{L}$ (12.3\%) at $\mathrm{PT}_{0.5-\mathrm{yr}}$. However, thinning significantly increased old-leaf specific leaf area (SLA) (16.6\%), and decreased old-leaf surface area (SA) (19.3\%), all-leaf (new and old) $\mathrm{L}$ (10.7\% and 6.6\%), chlorophyll a concentrations $\left(\mathrm{Chl}_{\mathrm{a}}\right)(23.8 \%$ and $21.6 \%), \mathrm{Chl}_{\mathrm{b}}(8.3 \%$ and $18.2 \%)$, chlorophyll total concentrations $\left(\mathrm{Chl}_{\mathrm{tot}}\right)(21.2 \%$ and $20.2 \%$ ) at $\mathrm{PT}_{2.5 \text {-yrs }}$ (Table 2). Thinning promoted $W$. japonica new-leaf elongation 0.5 year post-thinning, and then it made the leaves smaller and thicker, thereby reducing length and chlorophyll concentration.

For D. championii, thinning significantly decreased old-leaf SLA (12.5\%) at $\mathrm{PT}_{0.5 \text {-yr }}$, and also width $(\mathrm{W})(14.8 \%)$ and $\mathrm{Chl}_{\mathrm{b}}(6.9 \%)$ at $\mathrm{PT}_{2.5-\mathrm{yrs}}$. The results show that thinning led $D$. championii to produce narrow and thick leaves.

For D. dichotoma, thinning significantly increased new-leaf W (15.6\%), and decreased new-leaf SLA (12.2\%), $\mathrm{Chl}_{\mathrm{a}}(30.3 \%), \mathrm{Chl}_{\mathrm{b}}(21.9 \%), \mathrm{Chl}_{\text {tot }}(27.8 \%)$, and old-leaf $\mathrm{Chl}_{\mathrm{b}}(8.2 \%)$ at $\mathrm{PT}_{0.5 \text {-yr. }}$ At $\mathrm{PT}_{2.5-\mathrm{yrs}}$, thinning significantly increased old-leaf $\mathrm{L}$ 
307

308

(6.1\%), and decreased new-leaf SA (17.0\%), old-leaf W (11.1\%), all-leaf SLA (31.0\% and $23.2 \%), \mathrm{Chl}_{\mathrm{a}}(31.7 \%$ and $45.7 \%), \mathrm{Chl}_{\mathrm{b}}(29.7 \%$ and $44.9 \%)$, and $\mathrm{Chl}_{\text {tot }}(31.9 \%$ and $45.3 \%$ ). The results indicate that thinning promotes $D$. dichotoma leaf elongation 0.5 year post-thinning. After 2.5 years post-thinning, thinning makes leaves broader and thicker, but doesn't change leaf size, and thus chlorophyll concentration is low.

\section{Leaf gas exchange in the three dominant herbaceous plants}

For $W$. japonica, thinning significantly increased new-leaf dark respiration rate $(R d)$ (40.5\%), and decreased old-leaf apparent quantum efficiency (AQE) (23.6\%) at $\mathrm{PT}_{0.5-\mathrm{yr}}$ At $\mathrm{PT}_{2.5-\mathrm{yrs}}$, thinning significantly increased new-leaf net photosynthetic rate (A) $(66.6 \%)$, light saturation point $(L S P)(50.9 \%)$, old-leaf $R d(30.0 \%)$, and light compensation point (LCP) (100.0\%), and decreased old-leaf $A(38.3 \%)$, maximum net photosynthetic rate (Amax) (27.1\%), and all-leaf $A Q E$ (26.6\% and 48.6\%) (Fig. 2, 3 , and 4). These results show that thinning promoted $W$. japonica new-leaf carbon emissions after 0.5 year, and improved carbon fixation potential 2.5 years post-thinning. For old leaves, however, thinning promoted carbon emission and reduced carbon fixation potential and light use efficiency at both times.

For D. championii, thinning significantly increased new-leaf $R d(209.7 \%)$, old-leaf $A Q E(29.6 \%)$, all-leaf $A(80.9 \%$ and $48.3 \%), L S P(120.3 \%$ and $66.1 \%)$, and $\operatorname{Amax}(126.9 \%$ and $91.6 \%)$ at $\mathrm{PT}_{0.5-\mathrm{yr}}$. At $\mathrm{PT}_{2.5-\mathrm{yrs}}$, thinning significantly increased new-leaf $A(39.4 \%)$ and $A Q E(127.4 \%)$, and decreased old-leaf $A Q E(31.8 \%)$. Thinning improved D. championii leaf carbon fixation ability after 0.5 year, but only 
increased new-leaf light use efficiency 2.5 years post-thinning.

For $D$. dichotoma, thinning significantly increased new-leaf $A(43.8 \%), R d$ (29.8\%), and old-leaf $\operatorname{Amax}(16.0 \%)$ at $\mathrm{PT}_{0.5-\mathrm{yr}}$. Thinning also significantly increased old-leaf $A Q E$ (253.7\%), all-leaf $A$ (46.6\% and 75.6\%), LSP (28.7\% and 42.2\%), and $\operatorname{Amax}(45.4 \%$ and 68.1\%), and decreased new-leaf $R d(17.0 \%), A Q E(28.6 \%)$, and

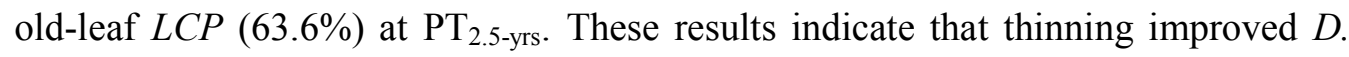
dichotoma old-leaf carbon fixation potential after 0.5 year, and increased all-leaf carbon fixation ability 2.5 years post-thinning.

\section{Discussion}

\section{Effects of thinning on understory communities}

Our results showed that thinning increased understory density and aboveground biomass, supported by previous studies (Lindgren et al. 2006; Sullivan et al. 2009). However, other studies reported little or negative effects after thinning (He and Barclay 2000; Wolk and Rocca 2009). Factors such as ecosystem-specific conditions (e.g., level of competition from other plants, plant community structure and diversity), thinning intensity, sampling time and time post-thinning, and responses to environmental conditions have a considerable influence on the results (Wolk and Rocca 2009; Taki et al. 2010).

Our results showed different responses to environmental conditions at the two post-thinning times (Table 1 and 3). The sudden changes in environmental conditions (especially light availability) post-thinning can be quickly used by certain species (such as D. championii and D. dichotoma) for propagation and growth (Zhang et al. 
351

352

353

354

355

356

357

358

359

360

361

362

363

364

365

366

367

368

369

370

371

372

2012; Gang et al. 2015). But the rapid growth of the remaining trees within 2.5 years

(reclosed the canopy) may limit the growth of new understory. This may be the reason why plant density and aboveground biomass at $\mathrm{PT}_{2.5 \text {-yrs }}$ was higher than at $\mathrm{PT}_{0.5-\mathrm{yr}}$, but aboveground biomass increase at $\mathrm{PT}_{2.5-\mathrm{yrs}}$ was lower than at $\mathrm{PT}_{0.5-\mathrm{yr}}$. Furthermore, nutrient availability may create competition among plants over the long term (Lochhead and Comeau 2012). Disturbance caused by thinning can change the photosynthetic capacity of understory (Fig. 2, 3 and 4); this may produce more complex understory communities. Adaptive strategy variation of different plant species may be another important reason led to these results, such as D. championii and $D$. dichotoma, although mean daily net photosynthetic rate of $D$. championii was maximum when total solar radiation transmittance was $50 \%$ like $D$. dichotoma, $D$. championii growth was the most robust when total solar radiation transmittance was 15-30\% (not 50\%) (Lv 2014; Wang 2014).

The significant diversity results we obtained were surprising given that other studies reported no response a short time post-thinning (Ishii et al. 2008; Taki et al. 2010). In those previous studies, it took more than three years before changes were observed in species diversity, although the canopy structures were altered by thinning. These differences may be related to thinning intensity, thinning time, or site-specific conditions (Wolk and Rocca 2009; Lindgren and Sullivan 2013). Our results suggested that canopy structure and light transmittance determined species number and richness, while soil conditions in the surface layer and light transmittance determined community dominance and uniformity (Table 3). Moreover, 
373 clean-up of shrubs may play an important role in relation to the immediate diversity

374 change, because herbs responded faster than shrubs and dominated the understory

375 after thinning (Lindgren and Sullivan 2013). The role of the dominate fern species as

376 an ecological filter that influences the emergence and establishment of the other

377 understory species and their patterns of seedling spatial distribution may be another

378 important influencing factors of understory diversity, and the mechanism of fern

379 interference was species-specific (George and Bazzaz 1999; Xu et al. 2014b).

380 Additional long-term surveys are required here to evaluate when the understory

381 diversity would become stable post-thinning.

\section{Effects of thinning on the leaf photosynthetic characteristics of the dominant}

\section{herbaceous plants}

Photosynthetic characteristics of the three dominant species showed different variation after 0.5 and 2.5 years post-thinning (Fig. 2, 3 and 4). Thinning significantly increased photosynthetic carbon sequestration ability of $W$. japonica new-leaf, D. championii all-leaf and D. dichotoma old-leaf, and decreased photosynthetic carbon sequestration ability of $W$. japonica old-leaf and breathing carbon loss ability of $D$. dichotoma new-leaf. Thinning influence on $D$. championii becomes smaller with time passing while its influence on $D$. dichotoma becomes bigger. This may explain why thinning significantly increased understory aboveground biomass at different rates. In July 2015, the aboveground biomass of three dominant herbaceous plants significantly increased by 169.2 and $418.1 \mathrm{~g} \mathrm{~m}^{-2}$ at $\mathrm{PT}_{0.5-\mathrm{yr}}$ and $\mathrm{PT}_{2.5-\mathrm{yrs}}$, this accounted for $47.9 \%$ and $94.7 \%$ of the total aboveground 
biomass increase, respectively (data not shown).

Leaf photosynthetic characteristics of the three species could not be explained in terms of the differences in environmental conditions (Table 3). Inter-specific differences may be the most important factors contributing to observed patterns depending on their various adaptive strategies (Ma et al. 2008; Wang et al. 2014; Chen et al. 2016). Generally, photosynthesis rate of most understory plants increases with light intensity enhancement after thinning within certain limits (Brouwer et al. 2012; Catoni et al. 2012). D. dichotoma is a light-demanding heliophyte, its growth was more robust when total solar radiation transmittance was higher (such as $50 \%$ ) (Lv 2014; Chen et al. 2016). So, D. dichotoma in our site grow better with time passing after thinning, because the total solar radiation transmittance were high after thinning (44.45\% and 42.94\%) (Table 1). W. japonica is a shade fern, too high light transmittance confined its photosynthesis rate increase and growth in the long run (Ma et al. 2008). D. championii is photophilous, but its growth was the most robust when total solar radiation transmittance was $15-30 \%$ and it always has a very significant positive correlation with $W$. japonica in the understory communities (Wang 2014; Wang et al. 2014). Then, D. championii in our site cannot always grow better with time passing after thinning. Light quality difference between the two time post-thinning may be another important factor due to its important role in fern spore germination and gametophyte growth (Brum and Randi 2002; Gang et al. 2015). Finally, intense competition between the three species may confuse their various photosynthetic responses to environmental conditions because of their similar 
417

418

419

420

421

422

423

424

425

426

427

428

resource usage and overlapping niches (Wu et al. 2013). Further investigations are needed to understand the deep effect of thinning on particular species (especially include multiple functional plant groups, such as shrub) photosynthesizes attributes and in favor of protection of plant diversity in subtropical China.

Leaf morphological attributes and chlorophyll content can partly explain the difference of leaf photosynthetic characteristics (Table 3). Generally, leaf size and chlorophyll a concentrations of most understory plants decreases with light intensity enhancement after thinning within certain limits (Brouwer et al. 2012; Wang 2014). At $\mathrm{PT}_{0.5-\mathrm{yr}}$, greater new-leaf length (or width) and lower old-leaf chlorophyll b concentration may show that understory produced bigger new leaves and reduced old-leaf chlorophyll photooxidative damage in order to acclimate to the higher light levels (Atanasova et al. 2003; Forrester et al. 2012). At PT 2.5 -yrs, old-leaf chlorophyll content was low due to the larger surface area and thicker cellular structure (Oguchi et al. 2003), and new-leaf size was small in support of direction adjustment to improve the light utilization efficiency of less light quantum on account of canopies reclose.

\section{Conclusion}

Understory density and aboveground biomass increased significantly 0.5 years after thinning and increased further 2.5 years post-thinning. The Shannon-Wiener index and Pielou index increased significantly, while the Simpson index decreased markedly after 0.5 and 2.5 years post-thinning. Species richness increased significantly after 0.5 year, and then decreased markedly 2.5 years post-thinning. 
439

440

441

442

443

444

445

446

447

Different age leaf photosynthetic characteristics of the three dominant species changed differently after 0.5 and 2.5 years post-thinning. Their photosynthetic characteristics cannot be together explained by environmental conditions depending on their various adaptive strategies, while these characteristics had some common responses to thinning in leaf morphological attributes and chlorophyll content.

Generally, new-leaf sizes increased first, and then decreased to adapt to the new light regime, while old leaves chlorophyll content gradually reducing. These results provide new insights into forest biodiversity and photosynthetic characteristics response to thinning in the short-term, and may be successfully used in a carbon balance algorithm for carbon model parameterization. We also suggest that other study pay close attention to the response of different functional plant groups to thinning in the future.

\section{Acknowledgments}

This research was funded by the NSFC Projects of International Cooperation and Exchanges (31210103920), the National Key Research and Development Program (2016YFD0600202), and the Project of Jiangxi Provincial Department of Science and Technology (20144BBB70005).

\section{References}

Arnon, D. I. 1949. Copper enzymes in isolated chloroplasts-Polyphenoloxodase in Beta-vulgaris. Plant physiology, 24(1): 1-15.

Atanasova, L., Stefanov D., Yordanov, I., Kornova, K., and Kavardzikov, L. 2003. Comparative characteristics of growth and photosynthesis of sun and shade 
leaves from normal and pendulum walnut (Juglans regia L.) trees. Photosynthetica, 41(2): 289-292.

Brouwer, B., Ziolkowska, A., Bagard, M., Keech, O., Gardeström, P. 2012. The impact of light intensity on shade-induced leaf senescence. Plant, Cell and Environment, 35: 1084-1098. doi: 10.1111/j.1365-3040.2011.02474.x.

Brum, F.R., and Randi, Á.M. 2002. High irradiance and temperature inhibit the germination of spores of the fern Rumohra adiantiformis (Forst.) Ching (Dryopteridaceae). Brazilian Journal of Botany, 25(4): 391-396.

Catoni, R., Gratani, L., and Varone, L. 2012. Physiological, morphological and anatomical trait variations between winter and summer leaves of Cistus species. Flora, 207(6): 442-449. http://dx.doi.org/10.1016/j.flora.2012.02.007.

Chen, Z.Q., Chen, Z.B., Yan, X.Y., and Bai, L.Y. 2016. Stoichiometric mechanisms of Dicranopteris dichotoma growth and resistance to nutrient limitation in the Zhuxi watershed in the red soil hilly region of China. Plant Soil, 398(1-2): 367-379. doi: 10.1007/s11104-015-2670-7.

Chiang, J.M., and Brown, K.J. 2010. The effects of thinning and burning treatments on within-canopy variation of leaf traits in hardwood forests of southern Ohio. Forest Ecology and Management, 260(6): 1065-1075. doi:10.1016/j.foreco.2010.06.033.

Forrester, D.I., Collopy, J.J., Beadle, C.L., Warren, C.R., and Baker, T.G. 2012. Effect of thinning, pruning and nitrogen fertilizer application on transpiration, photosynthesis and water-use efficiency in a young Eucalyptus nitens plantation. 
Forest Ecology and Management, 266: 286-300. doi:10.1016/j.foreco.2011.11.019.

Fu, X.L., Wang, J.L., Wang, H.M., Dai, X.Q., Yang, F.T., and Zhao, M. 2016. Response of the fine root production, phenology, and turnover rate of six shrub species from a subtropical forest to a soil moisture gradient and shading. Plant Soil, 399(1-2): 135-146. doi:10.1007/s11104-015-2686-z.

Gajardo-Caviedes, P.A., Espinosa, M.A., González, U.T., Ríos, and Darcy.G. 2005. The influence of thinning and tree size on the sapwood area / leaf area ratio in coigue. Canadian Journal of Forest Research-Revue Canadinenne De Recherche Forestiere, 35(7): 1679-1685. doi: 10.1139/X05-098.

Gang, Q., Yan, Q.L., and Zhu, J.J. 2015. Effects of thinning on early seed regeneration of two broadleaved tree species in larch plantations: implication for converting pure larch plantations into larch-broadleaved mixed forests. Forestry, 88(5): 573-585. doi:10.1093/forestry/cpv025.

George, L.O. and Bazzaz, F.A. 1999. The fern understory as an ecological filter: emergence and establishment of canopy-tree seedlings. Ecology, 80(3): 833-845.

Gspaltl, M., Bauerle, W., Binkley, D., Sterba, H. 2013. Leaf area and light use efficiency patterns of Norway spruce under different thinning regimes and age classes. Forest Ecology and Management, 288: 49-59.

doi:10.1016/j.foreco.2011.11.044.

Hanley, T.A., Deal, R.L., and Orlikowska, E.H. 2006. Relations between red alder composition and understory vegetation in young mixed forests of southeast 
Alaska. Canadian Journal of Forest Research-Revue Canadinenne De Recherche Forestiere, 36(3): 738-748. doi:10.1139/X05-290.

He, F.L., and Barclay, H.J. 2000. Long-term response of understory plant species to thinning and fertilization in a Douglas-fir plantation on southern Vancouver Island, British Columbia. Canadian Journal of Forest Research-Revue Canadinenne De Recherche Forestiere, 30(4): 566-572.

Ishii, H.T., Maleque, M.A., and Taniguchi, S. 2008. Line thinning promotes stand growth and understory diversity in Japanese cedar (Cryptomeria japonica D. Don) plantations. Journal of forest research, 13(1): 73-78. doi: 10.1007/s10310-007-0051-7.

Ji, L.Z., Wang, Z., Wang, X.W., and An, LL. 2011. Forest insect pest management and forest management in China: an overview. Environmental Management, 48(6): 1107-1121. doi: 10.1007/s00267-011-9697-1.

Li, X.F., Chen, Z.B., Chen, Z.Q., Zheng, L.D., Zhang, X.Y., and Li, R.L. 2013. Response of Disranopteris dichotoma growth to environmental factors in eroded red-soil region of southern China. Bull Soil Water Conserv, 33(3): 33-37.

Lindgren, P.M.F., Ransome, D.R., Sullivan, D.S., and Sullivan, T.P. 2006. Plant community attributes 12 to 14 years following precommercial thinning in a young lodgepole pine forest. Canadian Journal of Forest Research-Revue Canadinenne De Recherche Forestiere, 36(1): 48-61. doi:10.1139/X05-228.

Lindgren, P.M.F., and Sullivan, T.P. 2013. Influence of stand thinning and repeated fertilization on plant community abundance and diversity in young lodgepole 
pine stands: 15-year results. Forest Ecology and Management, 308: 17-30. http://dx.doi.org/10.1016/j.foreco.2013.07.020.

Liu, Z.F., Wu, J.P., Zhou, L.X., Lin, Y.B., and Fu, S.L. 2012. Effect of understory fern (Dicranopteris dichotoma) removal on substrate utilization patterns of culturable soil bacterial communities in subtropical Eucalyptus plantations. Pedobiologia-International Journal of Soil Biology, 55(1): 7-13. doi:10.1016/j.pedobi.2011.07.014.

Lochhead, K.D., and Comeau, P.G. 2012. Relationships between forest structure, understorey light and regeneration in complex Douglas-fir dominated stands in south-eastern British Columbia. Forest Ecology and Management, 284: 12-22. doi.org/10.1016/j.foreco.2012.07.029.

Lv, C.X. 2014. The photosynthetic physiological and ecological response of Dicranopterris dichotoma under the light intensity and 4 kinds of tree litter cover. Dissertation for the Degree of Master, Zhejiang A\&F University(in Chinese with English abstract).

Ma, Z.Q., Liu, Q.J., Xu, W.J., Li, X.R., and Liu, Y.C. 2008. A preliminary study on biomass of Woodwardia japonica community under a coniferous plantation in subtropical China. Chinese Journal of Plant Ecology, 32(1): 88-94(in Chinese with English abstract).

Magurran A.E. 1988. Ecological Diversity and its Measurements. Princeton, USA: Princeton University Press.

McDowell, N.C., Adams, H.D., Bailey, J.D., Hess, M., Kolb, T.E., 2006. Homeostatic 
maintenance of Ponderosa pine gas exchange in response to stand density changes. Ecological Applications, 16(3): 1164-1182. doi: 10.1890/1051-0761(2006)016[1164:HMOPPG]2.0.CO;2.

Moreno-Gutiérrez, C., Barberá, G.G., Nicolás, E., Luis, M.D., Castillo, M.V., Martínez-fernández, F., and Querejeta, J.I. 2011. Leaf $\delta^{18} \mathrm{O}$ of remaining trees is affected by thinning intensity in a semiarid pine forest. Plant, Cell and Environment, 34(6): 1009-1019. doi: 10.1111/j.1365-3040.2011.02300.x.

Nilsson, M.C., and Wardle, D.A. 2005. Understory vegetation as a forest ecosystem driver: evidence from the northern Swedish boreal forest. Frontiers in ecology and the environment, 3(8): 421-428.

Oguchi, R., Hikosaka, K., and Hirose, T. 2003. Does the photosynthetic light-acclimation need change in leaf anatomy? Plant, Cell and Environment, 26(4): 505-512.

Peng, S.L., Wang, D.X., Zhao, H., and Yang, T. 2008. Discussion the status quality of plantation and near nature forestry management in China. Journal of Northwest Forestry University, 23(2): 184-188(in Chinese with English abstract).

Piao, S.L., Fang, J.Y., Ciais, P., Peylin, P., Huang, Y., Sitch, S., and Wang, T. 2009. The carbon balance of terrestrial ecosystems in China. Nature, 458(7241): 1009-U82. doi:10.1038/nature07944.

Potvin, C., Lechowicz, M.J., and Tardif, S. 1990. The statistical analysis of ecophysiological response curves obtained from experiments involving repeated measures. Ecology, 71(4): 1389-1400. 
Raunikar, R., Buongiornoa, J., Turnerb, J.A., and Zhu, S.S. 2010. Global outlook for wood and forests with the bioenergy demand implied by scenarios of the Intergovernmental Panel on Climate Change. Forest Policy and Economics, 12(1): 48-56. doi:10.1016/j.forpol.2009.09.013.

Rodríguez-Calcerrada, J., Reich, P.B., Rosenqvist, E., Pardos, J.A., Cano, F.J., and Aranda, I. 2008. Leaf physiological versus morphological acclimation to high-light exposure at different stages of foliar development in oak. Tree Physioology, 28(5): 761-771. http://treephys.oxfordjournals.org/.

Sullivan, T.P., Sullivan, D.S., Lindgren, P.M.F., and Ransome, D.B. 2009. Stand structure and the abundance and diversity of plants and small mammals in natural and intensively managed forests. Forest Ecology and Management, 258(S): S127-S141. doi:10.1016/j.foreco.2009.06.001.

Taki, H., Inoue, T., Tanaka, H., Makihara, H., Sueyoshi, M., Isono, M., and Okabe, K. 2010. Responses of community structure, diversity, and abundance of understory plants and insect assemblages to thinning in plantations. Forest Ecology and Management, 259(3), 607-613. doi:10.1016/j.foreco.2009.11.019.

Wang, L.F., Ji, H.B., Bai, K.Z., Li, L.B., and Kuang, T.Y. 2006. Photosystem 2 activities of hyper-accumulator Dicranopteris dichotoma Bernh from a light rare earth elements mine. Photosynthetica, 44(2): 202-207.

Wang, X.Q. 2014. Study on In vitro culture and shade tolerance of Dryopteris championii. Dissertation for the Degree of Master, Beijing Forestry University(in Chinese with English abstract). 
Wang, X.Q., Zhang, T.T., Meng, Z., and Dong, L. 2014. In vitro Culture of Dryopteris championii (Benth.) C. Chr. from Spores. Plant Physiology Journal, 50(2): 159-163.

Wang, Y.D., Wang, Z.L., Wang, H.M., Guo, C.C., and Bao, W.K. 2012. Rainfall pulse primarily drives litterfall respiration and its contribution to soil respiration in a young exotic pine plantation in subtropical China. Canadian Journal of Forest Research-Revue Canadinenne De Recherche Forestiere, 42(4): 657-666. doi:10.1139/X2012-017.

Wang, Y.D., Wang, H.M., Xu, M.J., Ma, Z.Q., and Wang, Z.L. 2015. Soil organic carbon stocks and $\mathrm{CO}_{2}$ effluxes of native and exotic pine plantations in $\begin{array}{llll}\text { subtropical } & \text { China. } & \text { Catena, } & \text { 128: }\end{array}$ http://dx.doi.org/10.1016/j.catena.2015.02.003

Wen, X.F., Wang, H.M., Wang, J.L., Yu, G.R., and Sun, X.M. 2010. Ecosystem carbon exchanges of a subtropical evergreen coniferous plantation subjected to seasonal drought, 2003-2007. Biogeosciences, 7(1): 357-369. doi:10.5194/bg-7-357-2010, 2010.

Wolk, B., and Rocca, M.E. 2009. Thinning and chipping small-diameter ponderosa pine changes understory plant communities on the Colorado Front Range. Forest Ecology and Management, 257(1): 85-95. doi:10.1016/j.foreco.2008.08.014.

Wu, X.J., Zhang, Z.W., Meng, X.F., Li, Z., and Wang, Y.J. 2013. Dynamics of diversity, distribution patterns and interspecific associations of understory herbs in the city-suburb-exurb context of Wuhan city, China. Archives of biological 
sciences, 65(4): 1619-1628. doi:10.2298/ABS1304619W.

Xu, M.J., Wen, X.F., Wang, H.M., Zhang, W.J., Dai, X.Q., Song, J., Wang, Y.D., Fu, X.L., Liu, Y.F., Sun, X.M., and Yu, G.R. 2014a. Effects of Climatic Factors and Ecosystem Responses on the Inter-Annual Variability of Evapotranspiration in a Coniferous Plantation in Subtropical China. PLOS ONE, 9(1): e85593. doi:10.1371/journal.pone.0085593.

Xu, X.L., Li, Q.K., Wang, J.Y., Zhang, L.M., Tian, S.N., Zhi, L., Li, Q.R., and Sun, Y. 2014b. Inorganic and Organic Nitrogen Acquisition by a Fern Dicranopteris dichotoma in a Subtropical Forest in South China. PLoS ONE, 9(5): e90075. doi:10.1371/journal.pone.0090075.

Yan, J.H., Li, K., Peng, X.J., Huang, Z.L., Liu, S.Z., and Zhang, Q.M. 2015. The mechanism for exclusion of Pinus massoniana during the succession in subtropical forest ecosystems: light competition or stoichiometric homoeostasis? Scientific Reports, 5: 10994. doi:10.1038/srep10994.

Yan, J.H., Zhang, Y.P., Yu, G.R., Zhou, G.Y., Zhang, L.M., Li, K., Tan, Z.H., and Sha, L.P. 2013. Seasonal and inter-annual variations in net ecosystem exchange of two old-growth forests in southern China. Agricultural and Forest Meteorology, 182(SI): $257-265$. http://dx.doi.org/10.1016/j.agrformet.2013.03.002.

Yirdaw, E., and Luukkanen, O. 2004. Photosynthetically active radiation transmittance of forest plantation canopies in the Ethiopian highlands. Forest Ecology and Management, 188(1-3): 17-24. doi:10.1016/j.foreco.2003.07.024. 
Zhang, M., Zhu, J.J., and Yan, Q.L. 2012. Review on influence mechanisms of light in seed germination. Chinese Journal of Plant Ecology, 36(8): 899-908(in Chinese with English abstract). 
Table 1. Soil chemical properties, canopy structure and light transmittance after thinning in July 2015. The values are means \pm SE $(n=3)$. Different lowercase letters represent significant differences among treatments.

\begin{tabular}{|c|c|c|c|c|}
\hline \multicolumn{2}{|r|}{ Item } & \multirow{2}{*}{ Unthinned } & \multirow{2}{*}{$\mathrm{PT}_{0.5-\mathrm{yr}}$} & \multirow{2}{*}{$\mathrm{PT}_{2.5-\mathrm{yrs}}$} \\
\hline Soil depth & Chemical properties & & & \\
\hline \multirow{4}{*}{$0-10 \mathrm{~cm}$} & $\mathrm{pH}$ & $4.22 \pm 0.02 b$ & $4.23 \pm 0.03 b$ & $4.12 \pm 0.02 \mathrm{a}$ \\
\hline & $\mathrm{NH}_{4}^{+}-\mathrm{N}\left(\mathrm{mg} \mathrm{kg}^{-1}\right)$ & $8.15 \pm 0.34 \mathrm{~b}$ & $5.66 \pm 0.22 \mathrm{a}$ & $8.14 \pm 0.01 b$ \\
\hline & $\mathrm{NO}_{3}^{-}-\mathrm{N}\left(\mathrm{mg} \mathrm{kg}^{-1}\right)$ & $2.90 \pm 0.12 \mathrm{c}$ & $1.53 \pm 0.08 \mathrm{a}$ & $1.91 \pm 0.06 \mathrm{~b}$ \\
\hline & Inorganic $\mathrm{N}\left(\mathrm{mg} \mathrm{kg}^{-1}\right)$ & $11.05 \pm 0.22 \mathrm{c}$ & $7.60 \pm 0.33 \mathrm{a}$ & $9.70 \pm 0.09 b$ \\
\hline \multirow{4}{*}{$10-20 \mathrm{~cm}$} & $\mathrm{pH}$ & $4.23 \pm 0.01 \mathrm{a}$ & $4.21 \pm 0.02 \mathrm{a}$ & $4.20 \pm 0.01 \mathrm{a}$ \\
\hline & $\mathrm{NH}_{4}^{+}-\mathrm{N}\left(\mathrm{mg} \mathrm{kg}^{-1}\right)$ & $3.17 \pm 0.07 \mathrm{a}$ & $3.38 \pm 0.21 \mathrm{a}$ & $3.25 \pm 0.42 \mathrm{a}$ \\
\hline & $\mathrm{NO}_{3}^{-}-\mathrm{N}\left(\mathrm{mg} \mathrm{kg}^{-1}\right)$ & $1.28 \pm 0.12 b$ & $1.09 \pm 0.02 \mathrm{ab}$ & $0.84 \pm 0.06 \mathrm{a}$ \\
\hline & Inorganic $\mathrm{N}\left(\mathrm{mg} \mathrm{kg}^{-1}\right)$ & $4.45 \pm 0.15 \mathrm{a}$ & $4.46 \pm 0.18 \mathrm{a}$ & $4.23 \pm 0.26 \mathrm{a}$ \\
\hline \multicolumn{2}{|c|}{ Leaf area index (LAI) } & $3.15 \pm 0.05 b$ & $2.56 \pm 0.15 \mathrm{a}$ & $3.08 \pm 0.15 \mathrm{ab}$ \\
\hline \multicolumn{2}{|c|}{ Effective plant area index (PAIe) } & $3.02 \pm 0.04 \mathrm{~b}$ & $2.55 \pm 0.07 \mathrm{a}$ & $2.80 \pm 0.10 \mathrm{ab}$ \\
\hline \multicolumn{2}{|c|}{ Canopy openness (\%) } & $37.57 \pm 1.42 \mathrm{a}$ & $44.45 \pm 1.80 \mathrm{~b}$ & $42.94 \pm 1.30 \mathrm{ab}$ \\
\hline \multicolumn{2}{|c|}{ Total solar radiation transmittance $\left(\mathrm{T}_{\text {tot }}\right)(\%)$} & $37.94 \pm 1.10 \mathrm{a}$ & $55.15 \pm 1.53 b$ & $39.13 \pm 2.97 \mathrm{a}$ \\
\hline \multicolumn{2}{|c|}{ Direct solar radiation transmittance $\left(\mathrm{T}_{\mathrm{dir}}\right)(\%)$} & $35.43 \pm 0.83 \mathrm{a}$ & $55.20 \pm 1.09 b$ & $37.01 \pm 3.10 \mathrm{a}$ \\
\hline \multicolumn{2}{|c|}{ Diffuse solar radiation transmittance $\left(\mathrm{T}_{\mathrm{dif}}\right)(\%)$} & $35.43 \pm 1.37 \mathrm{a}$ & $55.10 \pm 1.97 \mathrm{~b}$ & $41.24 \pm 2.85 \mathrm{a}$ \\
\hline
\end{tabular}


Table 2. Effects of thinning on leaf morphological attributes and chlorophyll content of $W$. japonica, D. championii, and D. dichotoma in July 2015. The values are means $\pm \operatorname{SE}(n=3)$. Different lowercase letters represent significant differences among thinning treatments for the same leaf type. Different capital letters represent significant differences among leaf types for the same thinning treatment.

\begin{tabular}{|c|c|c|c|c|c|c|c|c|c|}
\hline Species & $\begin{array}{l}\text { Leaf } \\
\text { type }\end{array}$ & Treatment & $\begin{array}{l}\text { Length } \\
\text { (L) (cm) }\end{array}$ & $\begin{array}{c}\text { Width } \\
(\mathrm{W})(\mathrm{cm})\end{array}$ & $\begin{array}{l}\text { Surface area } \\
(\mathrm{SA})\left(\mathrm{cm}^{2}\right)\end{array}$ & $\begin{array}{c}\text { Specific leaf } \\
\text { area (SLA) }\left(\mathrm{cm}^{2}\right. \\
\left.\mathrm{g}^{-1}\right)\end{array}$ & $\begin{array}{c}\text { Chlorophyll a } \\
\text { concentration } \\
\left(\mathrm{Chl}_{\mathrm{a}}\right)\left(\mathrm{mg} \mathrm{g}^{-1} \mathrm{FW}\right)\end{array}$ & $\begin{array}{c}\text { Chlorophyll b } \\
\text { concentration } \\
\left(\mathrm{Chl}_{\mathrm{b}}\right)\left(\mathrm{mg} \mathrm{g}^{-1} \mathrm{FW}\right)\end{array}$ & $\begin{array}{l}\text { Chlorophyll total } \\
\text { concentration } \\
\left(\mathrm{Chl}_{\text {tot }}\right)\left(\mathrm{mg} \mathrm{g}^{-1} \mathrm{FW}\right)\end{array}$ \\
\hline \multirow{6}{*}{$\begin{array}{c}W . \\
\text { japonica }\end{array}$} & \multirow{3}{*}{ New } & Unthinned & $15.86 \pm 0.31 \mathrm{Ab}$ & $2.79 \pm 0.11 \mathrm{Aa}$ & $36.58 \pm 0.76 \mathrm{Aa}$ & $199.09 \pm 16.89 \mathrm{Ba}$ & $1.01 \pm 0.08 \mathrm{Ab}$ & $0.60 \pm 0.01 \mathrm{Bc}$ & $1.56 \pm 0.05 \mathrm{Ab}$ \\
\hline & & $\mathrm{PT}_{0.5-\mathrm{yr}}$ & $17.18 \pm 0.35 \mathrm{Ac}$ & $2.69 \pm 0.11 \mathrm{Aa}$ & $36.93 \pm 1.41 \mathrm{Aa}$ & $183.56 \pm 2.86 \mathrm{Ba}$ & $1.05 \pm 0.02 \mathrm{Ab}$ & $0.45 \pm 0.01 \mathrm{Aa}$ & $1.52 \pm 0.01 \mathrm{Ab}$ \\
\hline & & $\mathrm{PT}_{2.5 \text {-yrs }}$ & $14.17 \pm 0.18 \mathrm{Aa}$ & $2.82 \pm 0.03 \mathrm{Aa}$ & $34.15 \pm 0.51 \mathrm{Aa}$ & $201.08 \pm 6.69 \mathrm{Ba}$ & $0.77 \pm 0.02 \mathrm{Aa}$ & $0.55 \pm 0.01 \mathrm{Bb}$ & $1.23 \pm 0.02 \mathrm{Aa}$ \\
\hline & \multirow{3}{*}{ Old } & Unthinned & $20.56 \pm 0.21 \mathrm{Bc}$ & $3.32 \pm 0.14 \mathrm{Ba}$ & $50.22 \pm 0.73 \mathrm{Bb}$ & $134.55 \pm 5.83 \mathrm{Aa}$ & $1.53 \pm 0.03 \mathrm{Bb}$ & $0.55 \pm 0.01 \mathrm{Ab}$ & $2.18 \pm 0.10 \mathrm{Bb}$ \\
\hline & & $\mathrm{PT}_{0.5-\mathrm{yr}}$ & $18.03 \pm 0.26 \mathrm{Aa}$ & $3.23 \pm 0.10 \mathrm{Ba}$ & $48.25 \pm 0.52 \mathrm{Bb}$ & $131.92 \pm 1.86 \mathrm{Aa}$ & $1.41 \pm 0.04 \mathrm{Bb}$ & $0.51 \pm 0.02 \mathrm{Bb}$ & $1.93 \pm 0.06 \mathrm{Bab}$ \\
\hline & & $\mathrm{PT}_{2.5 \text {-yrs }}$ & $19.20 \pm 0.29 \mathrm{Bb}$ & $2.95 \pm 0.31 \mathrm{Aa}$ & $40.54 \pm 0.52 \mathrm{Ba}$ & $156.91 \pm 3.96 \mathrm{Ab}$ & $1.20 \pm 0.03 \mathrm{Ba}$ & $0.45 \pm 0.01 \mathrm{Aa}$ & $1.74 \pm 0.05 \mathrm{Ba}$ \\
\hline \multirow{3}{*}{$\begin{array}{c}D . \\
\text { championii }\end{array}$} & \multirow{3}{*}{ Old } & Unthinned & $17.71 \pm 0.23 \mathrm{a}$ & $3.99 \pm 0.08 b$ & $48.16 \pm 2.29 \mathrm{ab}$ & $131.2 \pm 6.59 \mathrm{~b}$ & $2.13 \pm 0.02 \mathrm{ab}$ & $0.72 \pm 0.01 \mathrm{~b}$ & $2.86 \pm 0.02 \mathrm{a}$ \\
\hline & & $\mathrm{PT}_{0.5-\mathrm{yr}}$ & $17.73 \pm 0.26 \mathrm{a}$ & $3.98 \pm 0.02 \mathrm{~b}$ & $51.98 \pm 3.91 \mathrm{~b}$ & $114.75 \pm 3.00 \mathrm{a}$ & $1.94 \pm 0.11 \mathrm{a}$ & $0.70 \pm 0.01 \mathrm{~b}$ & $2.74 \pm 0.04 \mathrm{a}$ \\
\hline & & $\mathrm{PT}_{2.5-\mathrm{yrs}}$ & $16.93 \pm 0.35 \mathrm{a}$ & $3.40 \pm 0.07 \mathrm{a}$ & $40.59 \pm 0.79 \mathrm{a}$ & $121.71 \pm 1.70 \mathrm{ab}$ & $2.33 \pm 0.05 \mathrm{~b}$ & $0.67 \pm 0.01 \mathrm{a}$ & $2.96 \pm 0.15 \mathrm{a}$ \\
\hline \multirow{6}{*}{$\begin{array}{c}D . \\
\text { dichotoma }\end{array}$} & \multirow{3}{*}{ New } & Unthinned & $14.40 \pm 0.60 \mathrm{Aab}$ & $2.71 \pm 0.08 \mathrm{Aa}$ & $30.96 \pm 1.04 \mathrm{Ab}$ & $262.28 \pm 2.51 \mathrm{Bc}$ & $2.08 \pm 0.05 \mathrm{Bb}$ & $0.64 \pm 0.01 \mathrm{Bc}$ & $2.70 \pm 0.07 \mathrm{Bb}$ \\
\hline & & $\mathrm{PT}_{0.5-\mathrm{yr}}$ & $15.95 \pm 0.47 \mathrm{Ab}$ & $3.21 \pm 0.13 \mathrm{Ab}$ & $34.39 \pm 1.38 \mathrm{Ab}$ & $233.81 \pm 1.32 \mathrm{Bb}$ & $1.45 \pm 0.01 \mathrm{Aa}$ & $0.50 \pm 0.01 \mathrm{Bb}$ & $1.95 \pm 0.01 \mathrm{Aa}$ \\
\hline & & $\mathrm{PT}_{2.5-\mathrm{yrs}}$ & $13.05 \pm 0.80 \mathrm{Aa}$ & $2.66 \pm 0.07 \mathrm{Aa}$ & $25.69 \pm 1.18 \mathrm{Aa}$ & $180.89 \pm 0.97 \mathrm{Ba}$ & $1.42 \pm 0.04 \mathrm{Ba}$ & $0.45 \pm 0.01 \mathrm{Ba}$ & $1.84 \pm 0.06 \mathrm{Ba}$ \\
\hline & \multirow{3}{*}{ Old } & Unthinned & $14.23 \pm 0.07 \mathrm{Aa}$ & $4.33 \pm 0.06 \mathrm{Bb}$ & $43.03 \pm 2.38 \mathrm{Ba}$ & $188.60 \pm 1.04 \mathrm{Ab}$ & $1.51 \pm 0.05 \mathrm{Ab}$ & $0.49 \pm 0.01 \mathrm{Ac}$ & $2.01 \pm 0.06 \mathrm{Ab}$ \\
\hline & & $\mathrm{PT}_{0.5-\mathrm{yr}}$ & $14.58 \pm 0.17 \mathrm{Aa}$ & $4.51 \pm 0.09 \mathrm{Bb}$ & $43.71 \pm 0.16 \mathrm{Ba}$ & $181.22 \pm 3.66 \mathrm{Ab}$ & $1.38 \pm 0.05 \mathrm{Ab}$ & $0.45 \pm 0.01 \mathrm{Ab}$ & $1.84 \pm 0.05 \mathrm{Ab}$ \\
\hline & & $\mathrm{PT}_{2.5 \text {-yrs }}$ & $15.10 \pm 0.10 \mathrm{Ab}$ & $3.85 \pm 0.09 \mathrm{Ba}$ & $40.07 \pm 2.33 \mathrm{Ba}$ & $144.88 \pm 2.02 \mathrm{Aa}$ & $0.82 \pm 0.01 \mathrm{Aa}$ & $0.27 \pm 0.01 \mathrm{Aa}$ & $1.10 \pm 0.01 \mathrm{Aa}$ \\
\hline
\end{tabular}


Table 3. Results of multiple stepwise regression analysis for the relationships of the understory community parameters (density, aboveground biomass, Species richness, Shannon-Wiener index, Simpson index and Pielou index) with the environmental conditions (soil inorganic nitrogen (IN), $\mathrm{NH}_{4}{ }^{+}-\mathrm{N}$, and $\mathrm{NO}_{3}{ }^{-} \mathrm{-N}$ in the 0-10 cm layer, canopy LAI, direct solar radiation transmittance $\left(\mathrm{T}_{\text {dir }}\right)$, diffuse solar radiation transmittance $\left(\mathrm{T}_{\text {dif }}\right)$ and total solar radiation transmittance $\left(\mathrm{T}_{\text {tot }}\right)$ ); the relationships of the leaf gas exchange (net photosynthetic rate $(A)$, dark respiration rate $(R d)$, light saturation point $(L S P)$, light compensation point $(L C P)$, apparent quantum efficiency $(A Q E)$, maximum net photosynthetic rate $(A \max )$ ) with the environmental conditions; and the relationships of the leaf gas exchange with the leaf morphological attributes and chlorophyll content (width (W), length (L), surface area (SA), specific leaf area (SLA), chlorophyll a concentration $\left(\mathrm{Chl}_{\mathrm{a}}\right)$, chlorophyll b concentration $\left(\mathrm{Chl}_{\mathrm{b}}\right)$ and chlorophyll total concentration $\left(\mathrm{Chl}_{\mathrm{tot}}\right)$ ) for all the treatments in July 2015. No correlations were found between the all-leaf ( $n=45$ ) (or same-type-leaf, $n=18$ or 27) leaf gas exchange of the three plant species with the environmental conditions for all the treatments.

\begin{tabular}{|c|c|c|c|c|c|}
\hline \multicolumn{2}{|c|}{ Dependent variable } & Regression equation & $n$ & $R^{2}$ & $P$ value \\
\hline \multicolumn{2}{|c|}{ Density } & $\mathrm{y}=2.37 \mathrm{NH}_{4}{ }^{+}-\mathrm{N}-1.77 \mathrm{NO}_{3}^{-}-\mathrm{N}+0.85$ & 18 & 0.73 & $\leq 0.001$ \\
\hline \multicolumn{2}{|c|}{ Aboveground biomass } & $\mathrm{y}=2.12 \mathrm{NH}_{4}^{+}-\mathrm{N}-2.14 \mathrm{NO}_{3}{ }^{-}-\mathrm{N}+3.22$ & 18 & 0.62 & $\leq 0.001$ \\
\hline \multicolumn{2}{|c|}{ Species richness } & $\mathrm{y}=1.35 \mathrm{LAI}+1.46$ & 18 & 0.34 & 0.011 \\
\hline \multicolumn{2}{|c|}{ Shannon-Wiener index } & $y=-0.66 T_{\text {dif }}+3.05$ & 18 & 0.35 & 0.008 \\
\hline \multicolumn{2}{|c|}{ Simpson index } & $\mathrm{y}=0.49 \mathrm{IN}+1.08 \mathrm{~T}_{\mathrm{dif}}-6.34$ & 18 & 0.61 & 0.001 \\
\hline \multicolumn{2}{|c|}{ Pielou index } & $\mathrm{y}=-0.33 \mathrm{NH}_{4}{ }^{+}-\mathrm{N}-0.33 \mathrm{~T}_{\mathrm{dir}}+1.35$ & 18 & 0.80 & $\leq 0.001$ \\
\hline \multirow{5}{*}{ New } & $A$ & $\mathrm{y}=-1.62 \mathrm{~L}-0.79 \mathrm{Ch}_{\mathrm{b}}+1.56 \mathrm{~W}+3.88$ & 18 & 0.66 & 0.001 \\
\hline & $R d$ & $\mathrm{y}=2.08 \mathrm{SA}-0.73 \mathrm{SLA}-3.84$ & 18 & 0.82 & $\leq 0.001$ \\
\hline & $L C P$ & $\mathrm{y}=-1.13 \mathrm{Chl}_{\mathrm{a}}+2.62$ & 18 & 0.58 & $\leq 0.001$ \\
\hline & $A Q E$ & $\mathrm{y}=2.03 \mathrm{SA}-1.60 \mathrm{~W}-8.34$ & 18 & 0.76 & $\leq 0.001$ \\
\hline & $\operatorname{Amax}$ & $\mathrm{y}=-0.74 \mathrm{Chl}_{\mathrm{a}}-0.88 \mathrm{~L}+3.62$ & 18 & 0.57 & 0.002 \\
\hline \multirow{6}{*}{ Old } & $A$ & $y=-1.66 \mathrm{SLA}-4.26 \mathrm{~L}+21.61$ & 27 & 0.71 & $\leq 0.001$ \\
\hline & $R d$ & $\mathrm{y}=-1.63 \mathrm{~W}+0.59 \mathrm{Chl}_{\mathrm{a}}+0.66 \mathrm{SLA}-2.39$ & 27 & 0.59 & $\leq 0.001$ \\
\hline & $L S P$ & $\mathrm{y}=-0.52 \mathrm{Chl}_{\mathrm{a}}+0.78 \mathrm{SA}+3.27$ & 27 & 0.40 & 0.002 \\
\hline & $L C P$ & $\mathrm{y}=7.25 \mathrm{~L}+3.11$ SLA- 34.45 & 27 & 0.77 & $\leq 0.001$ \\
\hline & $A Q E$ & $\mathrm{y}=-1.56 \mathrm{Chl}_{\mathrm{a}}-2.30 \mathrm{SLA}+1.49 \mathrm{~W}+7.12$ & 27 & 0.73 & $\leq 0.001$ \\
\hline & $\operatorname{Amax}$ & $\mathrm{y}=-2.65 \mathrm{~L}-0.77 \mathrm{Chl}_{\mathrm{a}}+1.53 \mathrm{SA}-0.94 \mathrm{SLA}+8.13$ & 27 & 0.74 & $\leq 0.001$ \\
\hline
\end{tabular}


Fig. 1. Species richness $(S)$, Shannon-Wiener index $\left(H^{\prime}\right)$, Simpson index $(D)$, and Pielou index $(J)$ after thinning in July 2015, and their variation between December 2014 and July 2015. The data are means \pm SE $(n=3)$. Different lowercase letters represent significant differences among treatments.
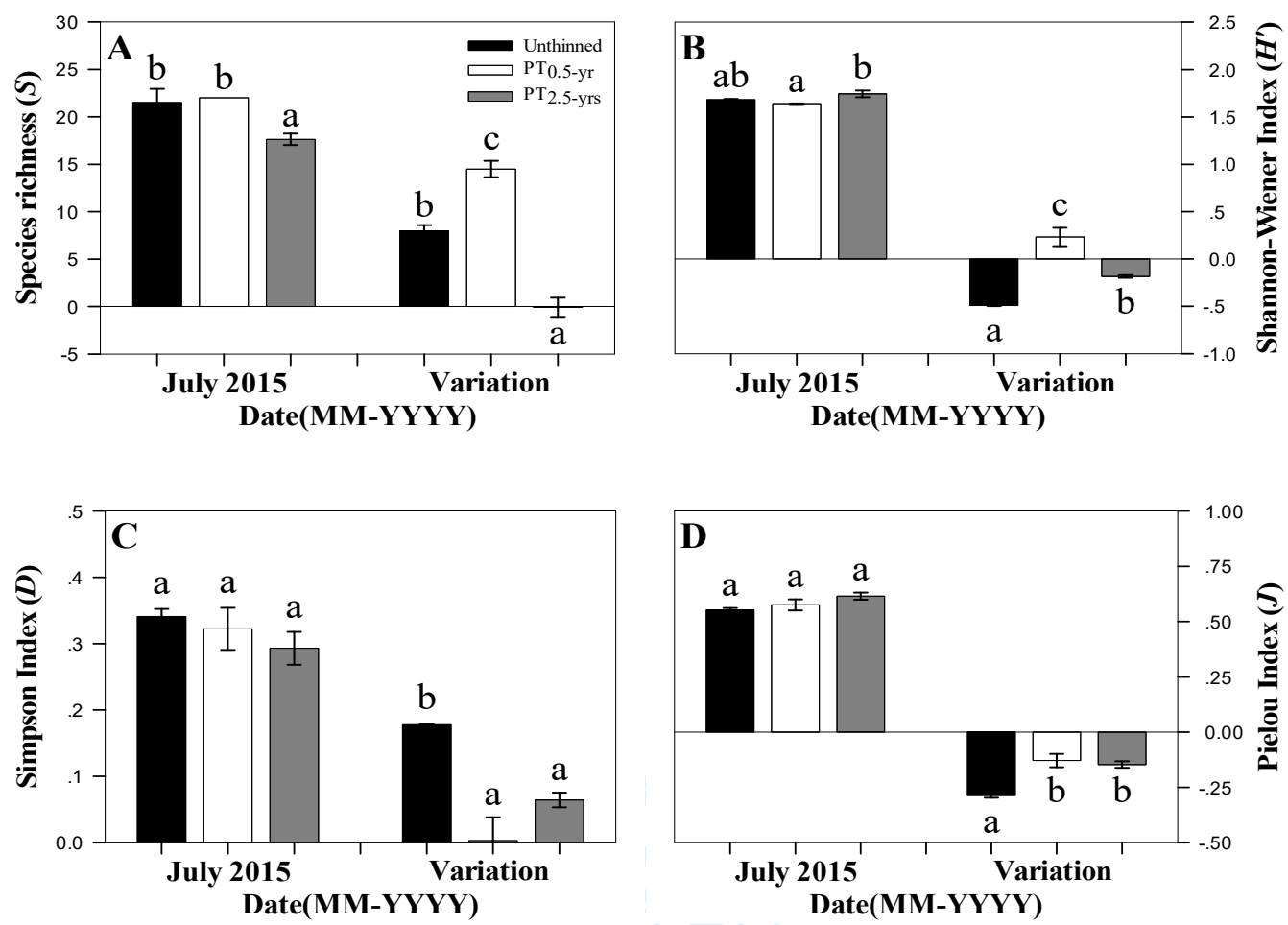
Fig. 2. Effects of thinning on net photosynthetic rate $(A)$ and dark respiration rate $(R d)$ of new and old leaves of W. japonica (A, D), D. championii (B, E), and D. dichotoma $(C, F)$ in July 2015. The data are means \pm SE $(n=3)$. Different lowercase letters represent significant differences among thinning treatments for the same leaf type. Different capitals letters represent significant differences among leaf types for the same thinning treatment.
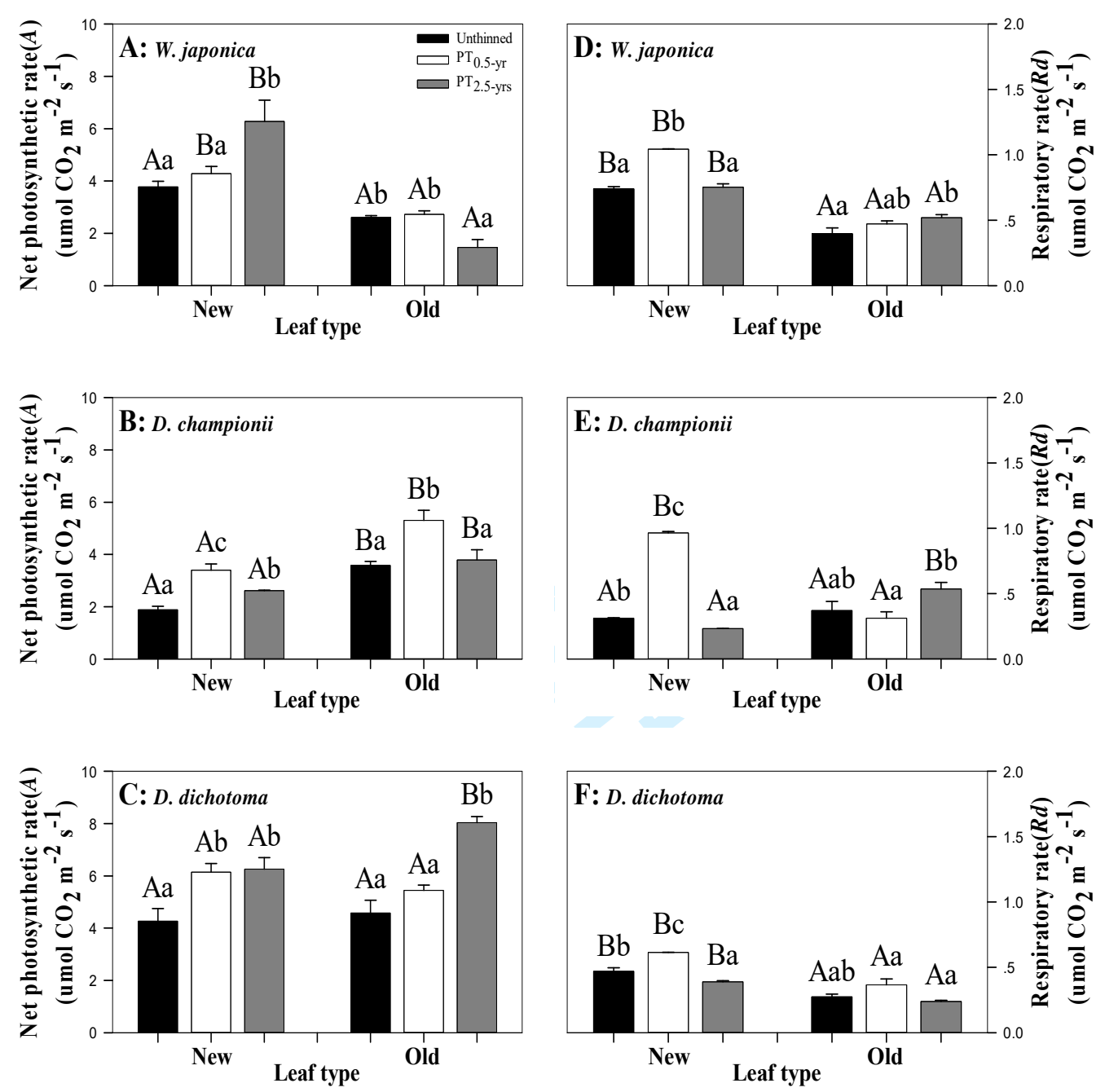
Fig. 3. Effects of thinning on light saturation point (LSP) and light compensation point $(L C P)$ of new and old leaves of W. japonica (A, D), D. championii (B, E), and D. dichotoma $(\mathrm{C}, \mathrm{F})$ in July 2015. The data are means $\pm \mathrm{SE}(n=3)$. Different lowercase letters represent significant differences among thinning treatments for the same leaf type. Different capitals letters represent significant differences among leaf types for the same thinning treatment.
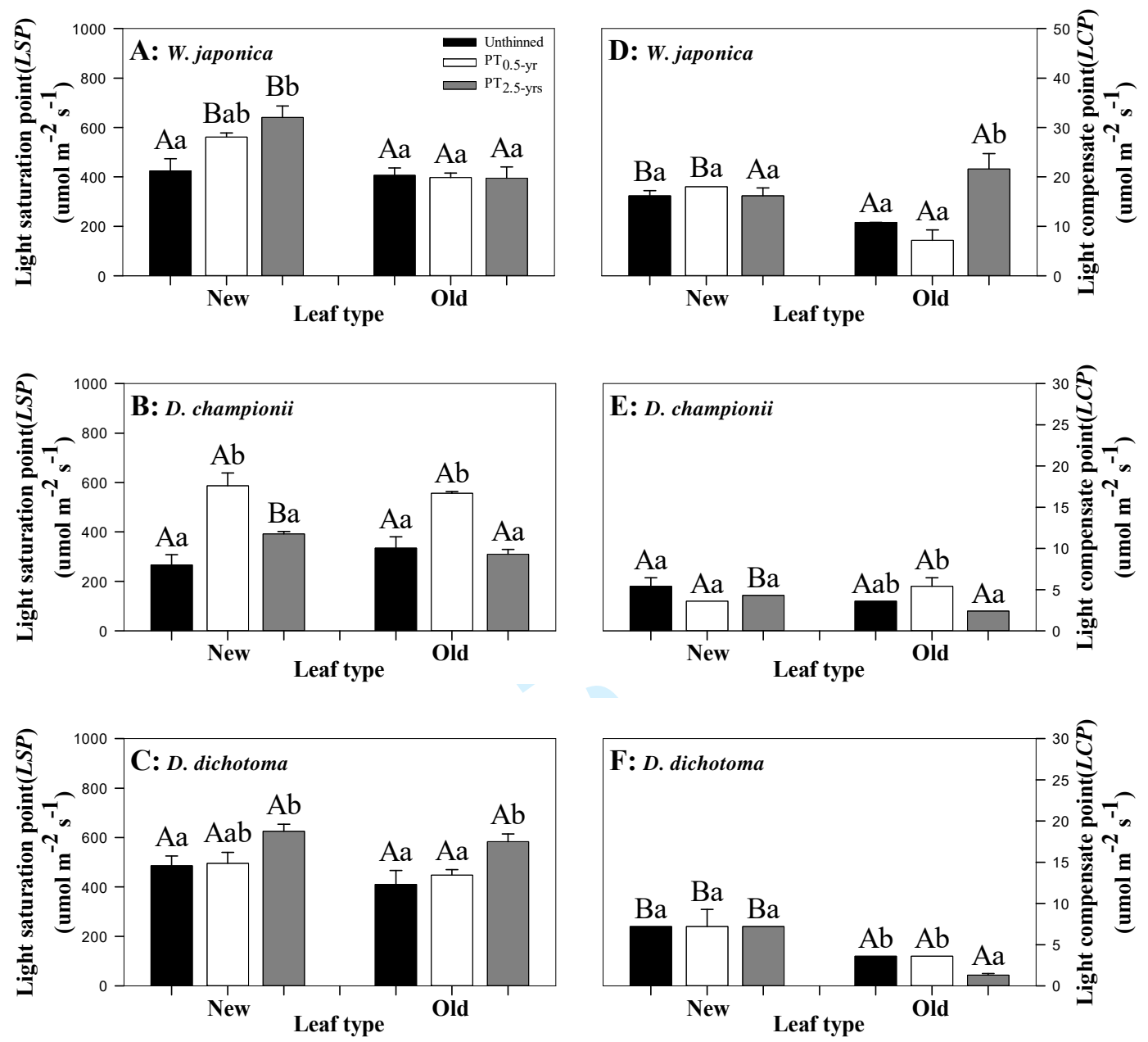
Fig. 4. Effects of thinning on apparent quantum efficiency $(A Q E)$ and maximum net photosynthetic rate (Amax) of new and old leaves of $W$. japonica (A, D), D. championii $(\mathrm{B}, \mathrm{E})$, and $D$. dichotoma $(\mathrm{C}, \mathrm{F})$ in July 2015. The data are means $\pm \mathrm{SE}$ $(n=3)$. Different lowercase letters represent significant differences among thinning treatments for the same leaf type. Different capitals letters represent significant differences among leaf types for the same thinning treatment.
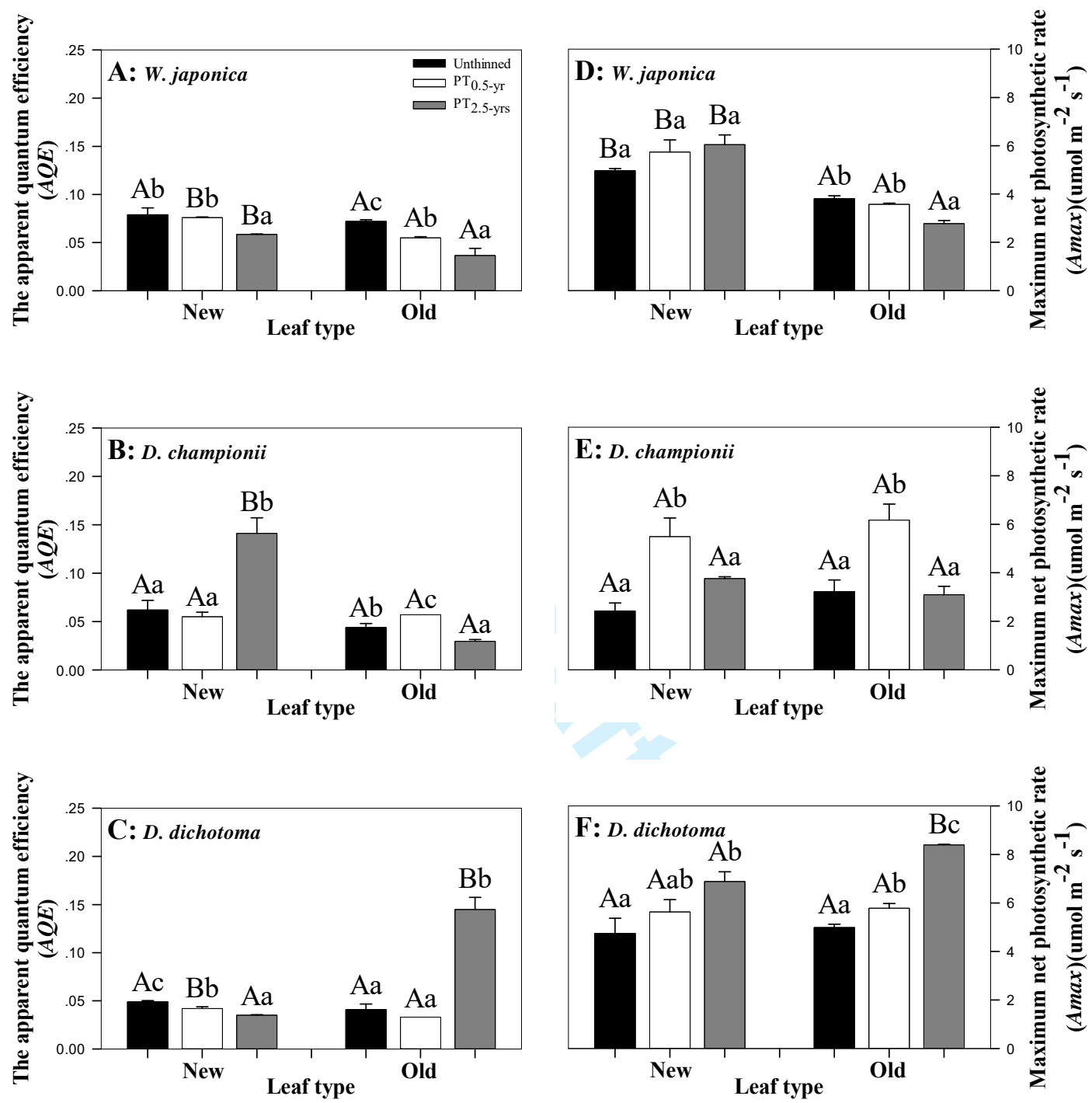
Table A1. Soil chemical properties, canopy structure and light transmittance, and understory community structure before thinning in December 2014. The values are means $\pm \mathrm{SE}(n=3)$. Different lowercase letters represent significant differences among treatments.

\begin{tabular}{|c|c|c|c|}
\hline \multicolumn{2}{|c|}{ Item } & \multirow{2}{*}{ Unthinned } & \multirow{2}{*}{$\mathrm{PT}_{0.5-\mathrm{yr}}$} \\
\hline Soil depth & Chemical properties & & \\
\hline \multirow{4}{*}{$0-10 \mathrm{~cm}$} & $\mathrm{pH}$ & $4.19 \pm 0.02 \mathrm{a}$ & $4.21 \pm 0.05 \mathrm{a}$ \\
\hline & $\mathrm{NH}_{4}^{+}-\mathrm{N}\left(\mathrm{mg} \mathrm{kg}^{-1}\right)$ & $3.54 \pm 0.06 \mathrm{a}$ & $3.91 \pm 0.30 \mathrm{a}$ \\
\hline & $\mathrm{NO}_{3}^{-}-\mathrm{N}\left(\mathrm{mg} \mathrm{kg}^{-1}\right)$ & $1.78 \pm 0.09 \mathrm{a}$ & $1.76 \pm 0.23 \mathrm{a}$ \\
\hline & Inorganic $\mathrm{N}\left(\mathrm{mg} \mathrm{kg}^{-1}\right)$ & $5.66 \pm 0.37 \mathrm{a}$ & $5.67 \pm 0.53 \mathrm{a}$ \\
\hline \multirow{4}{*}{$10-20 \mathrm{~cm}$} & $\mathrm{pH}$ & $4.30 \pm 0.02 \mathrm{a}$ & $4.30 \pm 0.03 \mathrm{a}$ \\
\hline & $\mathrm{NH}_{4}^{+}-\mathrm{N}\left(\mathrm{mg} \mathrm{kg}^{-1}\right)$ & $2.33 \pm 0.07 \mathrm{a}$ & $2.19 \pm 0.06 \mathrm{a}$ \\
\hline & $\mathrm{NO}_{3}^{-}-\mathrm{N}\left(\mathrm{mg} \mathrm{kg}^{-1}\right)$ & $1.52 \pm 0.20 \mathrm{a}$ & $1.20 \pm 0.18 \mathrm{a}$ \\
\hline & Inorganic $\mathrm{N}\left(\mathrm{mg} \mathrm{kg}^{-1}\right)$ & $3.85 \pm 0.13 \mathrm{a}$ & $3.45 \pm 0.23 \mathrm{a}$ \\
\hline \multicolumn{2}{|c|}{ Leaf area index (LAI) } & $3.62 \pm 0.08 \mathrm{a}$ & $3.80 \pm 0.06 \mathrm{a}$ \\
\hline \multicolumn{2}{|c|}{ Effective plant area index (PAIe) } & $3.38 \pm 0.08 \mathrm{a}$ & $3.64 \pm 0.03 b$ \\
\hline \multicolumn{2}{|c|}{ Canopy openness (\%) } & $35.19 \pm 2.48 \mathrm{a}$ & $37.03 \pm 1.09 \mathrm{a}$ \\
\hline \multicolumn{2}{|c|}{ Total solar radiation transmittance $\left(\mathrm{T}_{\text {tot }}\right)(\%)$} & $38.04 \pm 4.54 \mathrm{a}$ & $37.13 \pm 2.08 \mathrm{a}$ \\
\hline \multicolumn{2}{|c|}{ Direct solar radiation transmittance $\left(\mathrm{T}_{\mathrm{dir}}\right)(\%)$} & $36.33 \pm 5.37 \mathrm{a}$ & $36.46 \pm 2.48 \mathrm{a}$ \\
\hline \multicolumn{2}{|c|}{ Diffuse solar radiation transmittance $\left(\mathrm{T}_{\mathrm{dif}}\right)(\%)$} & $36.33 \pm 3.70 \mathrm{a}$ & $37.81 \pm 1.86 \mathrm{a}$ \\
\hline \multicolumn{2}{|c|}{ Species richness $(S)$} & $13.50 \pm 0.87 b$ & $7.50 \pm 0.87 \mathrm{a}$ \\
\hline \multicolumn{2}{|c|}{ Shannon-Wiener index $\left(H^{\prime}\right)$} & $2.17 \pm 0.00 \mathrm{~b}$ & $1.41 \pm 0.10 \mathrm{a}$ \\
\hline \multicolumn{2}{|c|}{ Simpson index $(D)$} & $0.16 \pm 0.01 \mathrm{a}$ & $0.32 \pm 0.01 \mathrm{~b}$ \\
\hline \multicolumn{2}{|l|}{ Pielou index $(J)$} & $0.84 \pm 0.02 \mathrm{~b}$ & $0.70 \pm 0.01 \mathrm{a}$ \\
\hline
\end{tabular}


Table A2. Density and aboveground biomass of the understory communities in December 2014 and July 2015. The values are means $(n=3)$. Different lowercase letters represent significant differences among thinning treatments at the two investigate dates. Different capital letters represent significant differences between the two investigate dates for the same thinning treatment.

\begin{tabular}{|c|c|c|c|c|c|c|c|c|}
\hline \multirow{3}{*}{ Species } & \multicolumn{6}{|c|}{ Density (Plants $\mathrm{m}^{-2}$ ) } & \multirow{3}{*}{$\begin{array}{l}\text { Density sum } \\
\left(\text { Plants } \mathrm{m}^{-2}\right)\end{array}$} & \multirow{3}{*}{$\begin{array}{c}\text { Above- } \\
\text { ground } \\
\text { biomass } \\
\text { sum }\left(\mathrm{g} \mathrm{m}^{-2}\right)\end{array}$} \\
\hline & \multicolumn{3}{|c|}{ Dec-2014 } & \multicolumn{3}{|c|}{ July-2015 } & & \\
\hline & Unthinned & $\mathrm{PT}_{0.5-\mathrm{yr}}$ & $\mathrm{PT}_{2.5 \text {-yrs }}$ & Unthinned & $\mathrm{PT}_{0.5-\mathrm{yr}}$ & $\mathrm{PT}_{2.5-\mathrm{yrs}}$ & & \\
\hline Woodwardia japonica (L. f.) Sm. & 1.10 & 2.50 & 14.40 & 2.60 & 11.95 & 21.80 & 54.35 & 677.71 \\
\hline Dryopteris championii (Benth.) C. Chr. & 6.90 & 3.20 & 7.87 & 7.30 & 9.20 & 14.20 & 48.67 & 269.63 \\
\hline Dicranopteris dichotoma (Thunb.)Bernh. & 0.50 & 5.47 & 5.70 & 2.00 & 10.80 & 36.40 & 60.87 & 218.94 \\
\hline Adiantum flabellulatum L. Sp. & 1.40 & 0.10 & 1.10 & 1.00 & 0.73 & 2.40 & 6.73 & 6.10 \\
\hline Parathelypteris glanduligera (Kze.) Ching & 0.13 & & & 1.47 & & & 1.60 & 3.50 \\
\hline $\begin{array}{l}\text { Pteridium aquilinum (Linn.) Kuhn var. latiusculum } \\
\text { (Desv.)Underw.ex Heller }\end{array}$ & & & & 0.80 & 0.33 & 0.04 & 1.17 & 5.93 \\
\hline Lophatherum gracile Brongn. & & & & 10.30 & 34.30 & 27.70 & 72.30 & 135.51 \\
\hline Isatis indigotica Fortune & & & & & 0.20 & 0.07 & 0.27 & 0.67 \\
\hline Imperata cylindrica (Linn.) Beauv. & & & & 10.60 & 0.60 & & 11.20 & 31.66 \\
\hline Amorphophallus rivieri Durieu & & & & & & 0.07 & 0.07 & 0.01 \\
\hline Glycyrrhiza uralensis Fisch. & & & & & 2.80 & 0.47 & 3.27 & 8.76 \\
\hline Oplismenus undulatifolius (Arduino) Beauv. & & & & & 0.27 & 0.10 & 0.37 & 0.47 \\
\hline Carex parva Nees & 0.50 & & 0.07 & & & & 0.57 & 0.21 \\
\hline Arundo donax Linn. & & & 0.07 & & & 0.40 & 0.47 & 1.07 \\
\hline Bupleurum chinensis DC. & & 0.07 & 0.07 & 3.00 & 0.60 & 0.53 & 4.27 & 9.68 \\
\hline Melastoma dodecandrum Lour. & 0.07 & & & 0.10 & 0.07 & & 0.23 & 0.90 \\
\hline Cyperus rotundus $\mathrm{L}$. & 0.07 & & & & & & 0.07 & 0.03 \\
\hline
\end{tabular}


Spatholobus suberectus Dunn

Uncaria rhynchophylla (Miq.) Miq. ex Havil.

Vitis amurensis Rupr.

Morinda umbellata Linn. subsp. obovata Y.Z.Ruan

Paederia scandens(Lour.) Merr.

Premna microphylla Turcz.

Viburnum dilatatum Thunb.

Glochidion puberum (Linn.) Hutch.

Psilopeganum sinense Hemsl.

Lonicera japonica Thunb.

Eurya muricata Dunn

Rubus corchorifolius Linn. f.

Smilax china Linn.

Smilax corbularia Kunth var. woodii (Merr.) T.Koyama

Ilex asprella (Hook. et Arn.) Champ. ex Benth.

Phlomis umbrosa Turcz.

Ficus pumila Linn.

Loropetalum chinense (R. Br.) Oliver

Vaccinium bracteatum Thunb.

Ardisia crenata Sims

Gardenia jasminoides Ellis

Camellia oleifera Abel.

Berchemia floribunda (Wall.)Brongn.

Symplocos paniculata (Thunb.) Miq.

\subsection{0}

$0.80 \quad 0.60$

0.07

0.30

0.07
0.13

0.20

0.33

0.33

0.20

\subsection{7}

$$
0.07
$$

$$
0.13
$$

$$
0.13
$$$$
0.60
$$

0.07

0.07

$\begin{array}{ll}0.10 & 0.40\end{array}$

0.13

0.90

0.90

0.07

0.13

0.20

$$
0.50
$$

\subsection{3}

\subsection{7}

\subsection{0}

0.60

0.33

0.13

0.02
0.82
0.41
2.13
0.69
5.59
0.03
0.55
0.32
0.13
0.29
0.08
22.73
0.70
11.13
7.33
1.00
2.30
0.50
229.79
4.67
2.36
3.60
6.67
1.70
0.50


Vitex negundo Linn. var. cannabifolia (Sieb.et Zucc.) Hand.-Mazz.

Syzygium grijsii (Hance) Merr. et Perry Rhaphiolepis indica (Linn.) Lindl.

Acer palmatum Thunb.

Rhamnus utilis Decne.

Rhus chinensis Mill.

Aralia chinensis Linn.

Sapium sebiferum (Linn.) Roxb.

Symplocos sumuntia Buch.-Ham. ex D. Don Quercus fabri Hance

Choerospondias axillaria (Roxb.) Burtt et Hill Sapindus mukorossi Gaertn.

Liquidambar formosana Hance

Michelia maudiae Dunn

Schima superba Gardn. et Champ.

Cinnamomum camphora (L.) Presl

$$
\text { Total density (Plants } \mathrm{m}^{-2} \text { ) }
$$

Total density variation (Plants $\mathrm{m}^{-2}$ )

Total aboveground biomass $\left(\mathrm{g} \mathrm{m}^{-2}\right)$

Total aboveground biomass variation $\left(\mathrm{g} \mathrm{m}^{-2}\right)$

\begin{tabular}{|c|c|c|c|c|c|c|c|}
\hline & & 0.13 & & & & 0.13 & 1.99 \\
\hline & & 0.07 & & & 0.40 & 0.47 & 3.11 \\
\hline \multirow[t]{12}{*}{0.90} & 0.07 & 0.20 & 0.40 & 0.30 & 0.10 & 1.97 & 10.67 \\
\hline & & & & 0.07 & 0.07 & 0.13 & 2.87 \\
\hline & & & 0.10 & 0.13 & & 0.23 & 0.46 \\
\hline & & & 0.07 & 0.07 & & 0.13 & 0.98 \\
\hline & & & 0.07 & & & 0.07 & 0.04 \\
\hline & & & 0.07 & & & 0.07 & 1.84 \\
\hline & & & & 1.20 & & 1.20 & 1.15 \\
\hline & & & 0.07 & & & 0.07 & 0.08 \\
\hline & & & & 0.07 & 0.40 & 0.47 & 3.55 \\
\hline & & & 1.50 & 2.10 & 0.90 & 4.50 & 22.87 \\
\hline & 0.07 & & 0.07 & 0.20 & & 0.33 & 4.34 \\
\hline & 0.13 & & & 0.07 & & 0.20 & 1.84 \\
\hline \multirow[t]{2}{*}{0.07} & & 0.30 & 0.07 & 0.20 & 0.20 & 0.83 & 6.74 \\
\hline & & & & 0.07 & & 0.07 & 0.24 \\
\hline \multirow[t]{2}{*}{ 13.70Aa } & $12.37 \mathrm{Aa}$ & $31.83 \mathrm{Ab}$ & $45.90 \mathrm{Ba}$ & $94.05 \mathrm{Bb}$ & $111.24 \mathrm{Bc}$ & 309.09 & \\
\hline & & & $32.20 \mathrm{a}$ & $81.68 \mathrm{a}$ & $79.41 \mathrm{~b}$ & & \\
\hline \multirow[t]{2}{*}{$82.42 \mathrm{Aa}$} & $70.48 \mathrm{Aa}$ & $238.19 \mathrm{Ab}$ & $184.66 \mathrm{Ba}$ & $537.52 \mathrm{Bb}$ & $626.32 \mathrm{Bc}$ & & 1739.59 \\
\hline & & & $102.24 \mathrm{a}$ & $467.03 \mathrm{c}$ & $388.13 b$ & & \\
\hline
\end{tabular}


Fig. A1. Sketch map of the understory survey.

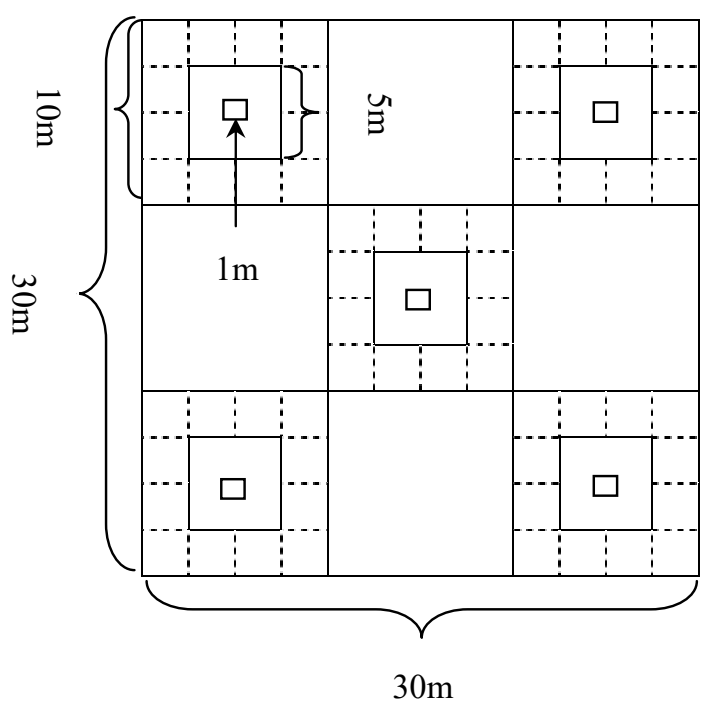

